This is the accepted, but not typeset version of the paper:

Öllerer K., Varga A., Kirby K., Demeter L., Biró M., Bölöni J. and Molnár Z.

Beyond the obvious impact of domestic livestock grazing on temperate forest vegetation - A global review. Biological Conservation 237: 209-219.

DOI: https://doi.org/10.1016/j.biocon.2019.07.007

\title{
Beyond the obvious impact of domestic livestock grazing on temperate forest vegetation - A global review
}

\author{
Kinga Öllerer ${ }^{1,2 * \ddagger}$, Anna Varga $^{1 \ddagger}$, Keith Kirby $^{3}$, László Demeter ${ }^{1}$, Marianna Biró ${ }^{1}$, János Bölöni ${ }^{1}$, \\ Zsolt Molnár ${ }^{1}$ \\ ${ }^{1}$ Institute of Ecology and Botany, MTA Centre for Ecological Research, Vácrátót, Hungary \\ ${ }^{2}$ Institute of Biology Bucharest, Romanian Academy, Bucharest, Romania \\ ${ }^{3}$ Department of Plant Sciences, University of Oxford, UK \\ ${ }^{\ddagger}$ These authors have contributed equally to this work.
}

Corresponding author

Email: kinga.ollerer@gmail.com

\begin{abstract}
Large herbivores have a keystone role in many forest ecosystems. There is widespread recognition that undesirable changes may be caused by the complete removal of grazing-related disturbances, whereas there can be benefits from properly managed, targeted livestock grazing, both from a forest management and biodiversity perspectives. However, there are also many contradictory statements and results about forest grazing. We summarize the main scientific evidence and knowledge gaps on forest livestock grazing through a global review of the literature for the temperate region. We analysed 71 publications discussing the impact of livestock grazing on vegetation in forests. Grazing reduces vegetation biomass, but less obvious effects relevant to conservation include increased habitat diversity and increased regeneration of selected canopy tree species. Moreover, detailed guidance on how grazing should be carried out for conservation purposes is limited because the results are strongly context dependent. The direction and amplitude of effects can be influenced not only by forest type and stocking levels, but by foraging preferences of livestock, availability of alternative forage, grazing season and herder activity. We stress the need for well-planned real-world experiments and observations, and for more quantitative studies to foster evidence-based conservation management. Grazing differences between wild ungulates and livestock should be better studied, because the effects are often overlapping. We suggest widening the temporal and spatial scales of case studies and stress the need to create space and openness for interdisciplinary and participatory research and conservation approaches, initiating knowledge co-production on the benefits and dis-benefits of grazing in forests.
\end{abstract}

Keywords: biodiversity; conservation grazing; knowledge gaps; silvopastoral systems; targeted grazing; vegetation management 


\section{Highlights:}

- Targeted livestock grazing can benefit both forest management and biodiversity.

- We reviewed 71 papers on the vegetation impact in temperate forests.

- Grazing can increase habitat diversity and regeneration of canopy tree species.

- Impacts are highly contextual but local factors are often not properly documented.

- Approaches and attitudes towards livestock forest grazing should be reconsidered.

\section{Graphical abstract:}

Impacts of grazing by domestic livestock on forest elements
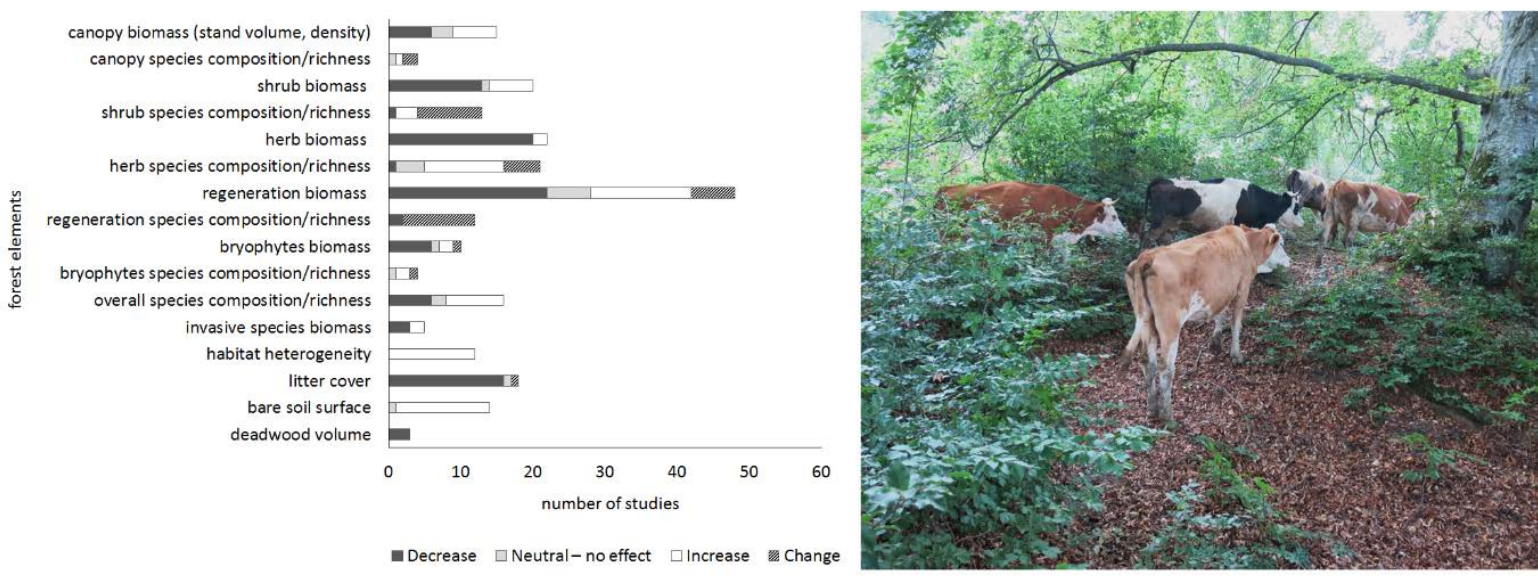


\section{Introduction}

Large herbivores, both wild and domestic, are keystone species in many forest ecosystems through their long-term and large-scale influence on ecological functioning. Herbivores influence the extent of forests through limiting or facilitating their spread on to open ground, their structure and openness, the composition of the tree, shrub and ground flora, with indirect effects then on the fauna (Adams, 1975; Rackham, 1980; Putman, 1996; Belsky and Blumenthal, 1997; Ramirez et al., 2018). Livestock grazing in European and Asian temperate forests has a long history, following the gradual displacement of wild herbivores and domestication (Buffum et al., 2009; Rotherham, 2013), but was introduced to North and South America, Australia and New Zealand a few centuries ago (Borman, 2005; Mazzini et al., 2018). This paper reviews what we know, and do not know, about livestock grazing in temperate forest systems, aiming to provide new insights that may help foster discussion, research and experimentation on and employment of this historical but often disputed practice.

There is an ongoing debate as to the extent to and manner in which grazing and browsing by large herbivores influenced the structure and dynamics of the natural forest (Vera, 2000; Mitchell, 2005) and in derived cultural landscapes (Rackham, 1980; Rotherham, 2013). Their impacts extend, however, from altering the composition and structure of the vegetation at a point to wider effects through altering nutrient cycles (Adams, 1975; Bernes et al., 2018) and ultimately the balance between grasslands and open and closed forests in the landscape (Rackham, 1980; Vera, 2000; Rotherham, 2013; Poschlod, 2015). Within the temperate region there are few large natural forests (Burrascano et al., 2013) that retain a full suite of large native herbivores. Even in parts of the world where wild herbivores still predominate, they may be joined or replaced by a variety of native and introduced livestock such as cattle, sheep and ponies (Putman, 1996; Tubbs, 1997; Vera, 2000; Bernes et al., 2018). Livestock may have different impacts to past and present wild herbivore populations because of differences in their physiology, diet, behaviour, numbers and management (Kingery and Graham, 1991; Walker et al., 2015; Bernes et al., 2018; Cromsigt et al., 2018). Lack of awareness of these differences has created tensions and some foresters have sought to reduce livestock grazing, leading to bans in some countries at some periods (Kardell, 2016; Nichiforel et al., 2018). More recently there has been increasing advocacy of livestock grazing, because there is more potential to control both density and season of grazing, in comparison with wild herbivores (Hester et al., 1996). Grazing has also been introduced as a component of 'rewilding' mainly in semi-open habitats, such as woodpastures (Smit et al., 2015; Cromsigt et al., 2018).

Assessments of the impact that grazing in forests is complicated by a general shift from multipleuse to single-commodity forest uses in the last two centuries (Rotherham, 2013; Samojlik et al., 2016). Livestock and game management came to be seen as competitors to timber production (Graham et al., 2010; Kardell, 2016). Livestock grazing, seen from the commercial forestry point of view, became an undesirable practice that should be completely taken out of the forests (Dambach, 1944; Kardell, 2016; Bernes et al., 2018; Nichiforel et al., 2018). This attitude has been hardened by increases in stocking rates of domestic livestock, compounded by more recent increases in wild ungulates (Putman, 1996; Bernes et al., 2018). The removal of livestock as a response to such situations has led to the disappearance of complex and specific disturbance patterns that in turn have triggered new conservation and ecological issues (Mitchell and Kirby, 1990; Kirby et al., 1994; Cooper and McCann, 2011).

Attitudes towards forest grazing by livestock are however changing. There is renewed interest for multiple-use systems and traditional, often abandoned historical practices, including the combination of pasturing and forestry, shown by the increasing number of studies on wood-pastures (Hartel and Plieninger, 2014) and initiatives towards silvopastoral management (Mosquera-Losada et al., 2005). Traditional practices are seen as providing both economic and ecological benefits, but also promoted in recognition of the rights of local communities and people with traditional occupations (Díaz et al., 2015). The implications for cultural traditions and rights of local communities relying on livestock husbandry have however generally been underrepresented in this debate (Norbu, 2002; Buffum et al., 2009; Shakeri et al., 2012). 
Alongside the world-wide acknowledged negative effects of overgrazing (Dambach, 1944; Mitchell and Kirby, 1990; Noack et al., 2010; Milios et al., 2014), properly managed livestock grazing is recognized for its potential silvicultural, agroforestry, conservation and overall vegetation management benefits (Adams, 1975; Kirby et al., 1994; Thomason, 1995; Humphrey and Patterson, 2000; Lamoot et al., 2005; Chauchard et al., 2006; Darabant et al., 2007; McEvoy and McAdam, 2008). Yet research on these potential benefits has been limited and mainly qualitative.

The impacts of large wild herbivores (Gill, 1992; Putman, 1996; Ramirez et al., 2018), or domestic and wild herbivores have mainly been discussed together (Mitchell and Kirby, 1990; Kirby et al., 1994; Bernes et al., 2018). To our knowledge, there are only early (Adams, 1975) or regional (Belsky and Blumenthal, 1997 - USA, the Interior West; Mazzini et al., 2018 - South America) reviews available on the vegetation impacts of livestock alone in temperate forests. We lack studies and understanding of the complex mechanisms (the impacts of different grazing regimes and interacting effects of grazing, trampling, manuring and forest history) that can give rise to different outcomes (Mitchell and Kirby, 1990; Kirby et al., 1994; Bernes et al., 2018; Mazzini et al., 2018). Such an understanding would help in planning and conducting targeted grazing for conservation management.

In this paper we review the impact of livestock grazing on vegetation in temperate forests at a global level. The reduction of vegetation biomass by grazing is well-known, so we focused on the less obvious effects and on the findings of comparative studies, i.e. not just grazing versus no grazing, but the effect of different levels of grazing. We identify knowledge gaps, and formulate recommendations for future research that could support the development of management plans harnessing the vegetation management, conservation and silvicultural potential of livestock forest grazing.

\section{Methods}

A literature search was conducted on 15 February 2017 in the Web of Science (WoS) database, using the query formula 'TOPIC: ((forest OR wood* OR grove OR stand OR acorn OR silvopast*) NEAR (graz* OR brows* OR pastur* OR herd* OR pannag*))', with no limit for time-span or language. The search yielded 9512 titles. The initial title screening reduced the list further down to 586 , which were then checked for abstract, keywords and location, leaving 147 titles where the full text was downloaded for thorough analysis.

Papers were excluded at this stage if they focussed only on wild ungulates or considered habitats other than temperate forests, based on the vegetation, location and the geographic boundaries reported for the temperate forest biomes (Olson et al., 2001). Localization of study sites was performed using ArcGIS version 10.1 (ESRI, 2012). From the bibliographies of these papers, we selected further titles of potential interest for detailed scrutiny. In total 67 relevant publications were identified.

The search was repeated on 30 September 2018, yielding 10609 hits, refined to 644 by the initial screening. Once duplicates were removed, and secondary checking for abstract, keywords and location carried out, four new publications were added to the list. Thus, our analysis was based on 71 publications ( 57 from the WoS database and 14 from bibliography searches; Supporting information S1). Unless specified otherwise, under the term grazing we are referring to the entire complex process, including grazing, browsing, trampling, etc.

The selected studies covered almost 75 years of publication history, varied greatly in their methodology, with a heterogeneous mixture of study sites. Potentially critical information on the study conditions were often missing (see next section). Therefore, we felt it more useful to conduct a classic review instead of a meta-analysis, where there was a higher risk of losing ecological meaning or misinterpretation. 


\section{Results}

\subsection{Characteristics of the studies included}

\subsubsection{Study locations, habitat types and grazer species}

The great majority of the studies in the final selection were from Europe (Fig. 1), particularly from the United Kingdom (17 studies), followed by North America. There were relatively few studies from regions where traditional livestock forest grazing is still widely practiced e.g. from the temperate forests of Asia (Buffum et al., 2009) and the non-Mediterranean Southern Europe (Papachristou and Platis, 2011).

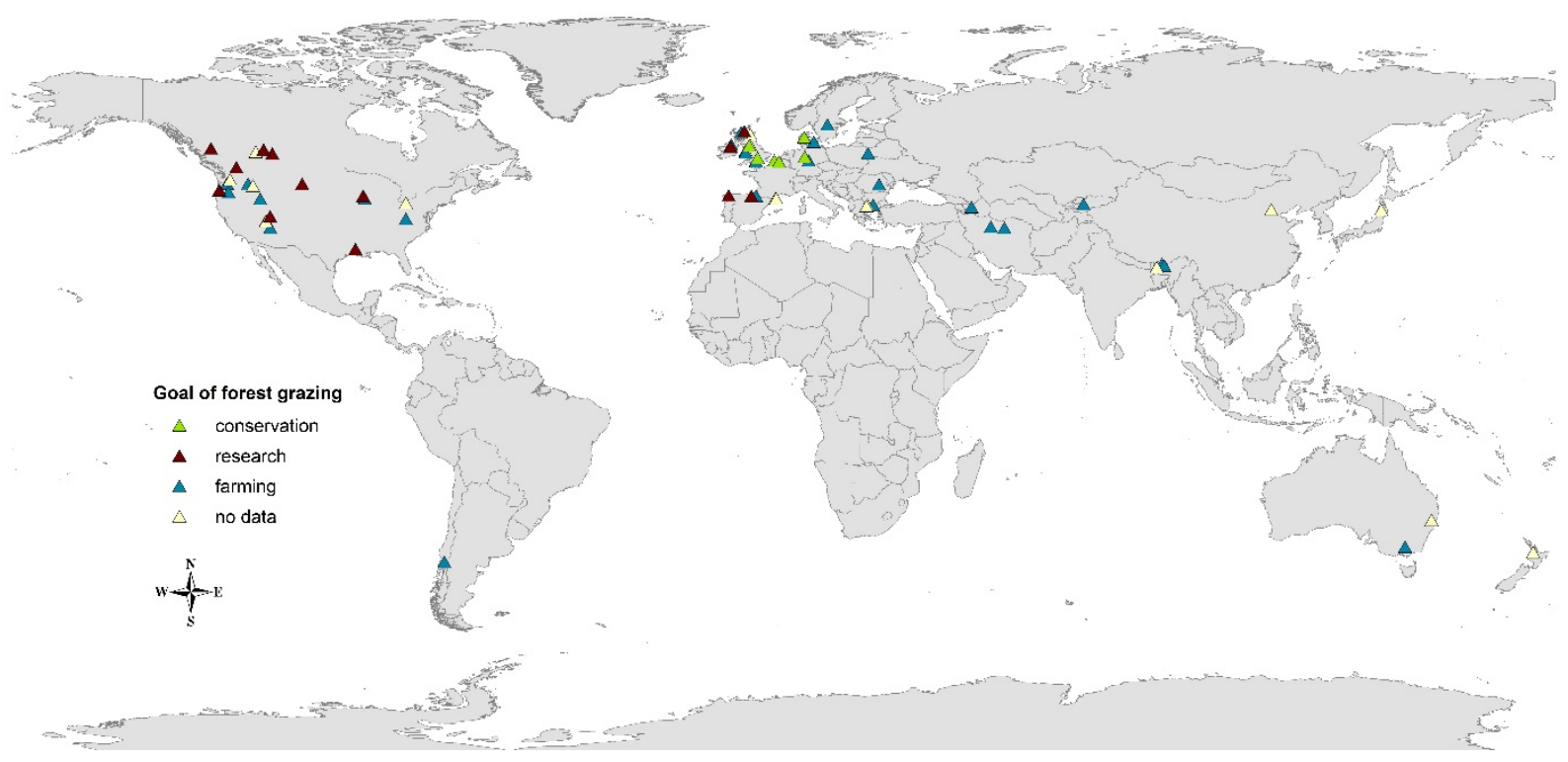

Fig. 1. Location of the studies considered in the review and the main goals of forest grazing (basemap source: ArcGIS.10.1.ESRI/ArcGIS_online world countries)

Around one third (28) of the studies were conducted in European broadleaf forests, followed by North American conifer forests (12), and North American (8) and Asian (7) broadleaf forests (Supporting information Fig. S1). The great majority (56) of the studies were conducted in natural/semi-natural forests, six in a combination of natural and plantation forests, eight in plantations and for one no data was provided regarding origin. This classification is based on the original authors' description, though we recognise that there may not always be a clear-cut distinction. The young plantations included areas that were previously managed as forest, but also new plantations on formerly open habitats such as pastureland.

The earliest publication dated from 1944, but over $60 \%$ of the reviewed papers were published after the year 2000, reflecting increased interest in this topic (Supporting information Fig. S2). General reviews referred to archive data and forest grazing history from the Medieval period onwards, but mostly the last 250 years (e.g. Mitchell and Kirby 1990; Thomason, 1995). However, the majority of the reviewed studies provided data from the mid- $20^{\text {th }}$ century onwards. It is interesting to highlight that the studied period was mentioned only in around $50 \%$ of the reviewed papers.

Over half the studies involved only one grazing animal species, with cattle being the most common. There was only one study (Van Uytvanck and Hoffmann, 2009) clearly stating that large wild herbivores were absent in the study area. In 23 studies wild ungulate presence was mentioned, but the authors claimed that they were in low numbers and the impact was negligible in comparison with livestock. There was only one study that clearly differentiated wild herbivore and cattle impact (Walker et al., 2015). 


\subsubsection{Study objectives and methodologies}

Most studies focussed on the effects of livestock grazing on vegetation composition, tree regeneration and stand structure (Fig. 2). Only two studies discussing vegetation effects had 'observing livestock behaviour' as their main focus and only 12 included observations on animal behaviour. There was only one study that was based on interviewing stakeholders (Mayerfeld et al., 2016) and another one in which such interactions with locals were mentioned (Buffum et al., 2009).

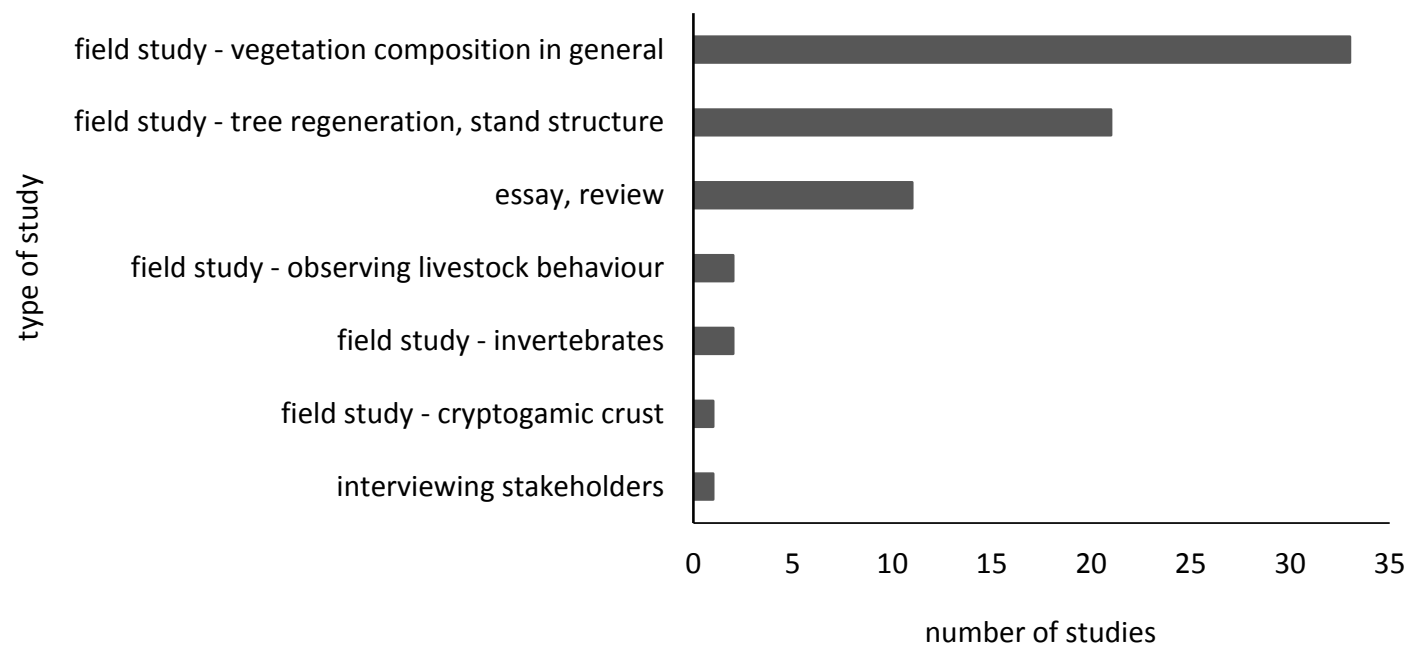

Fig. 2. The primary objectives and methodology of the studies considered in the review

\subsubsection{Study design}

Sixty-five percent of the 60 primary research papers, thus excluding the 11 essays and reviews, were based on the comparison of at least two grazing conditions, but most just compared grazing versus lack of grazing conditions (Fig. 3).

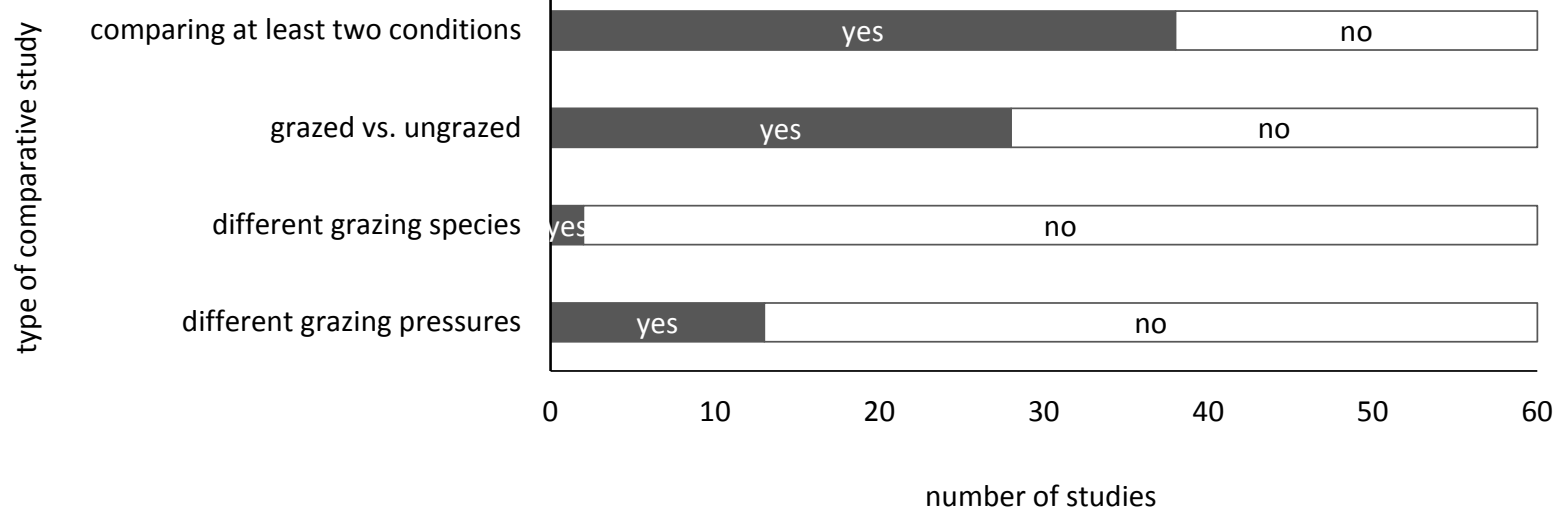

Fig. 3. The amount and type of comparative studies within the reviewed papers 
There were only two studies comparing the vegetation impacts of at least two different grazer species, and only 13 compared different grazing pressures.

Information on previous land-use (including grazing) history and the situation preceding the study was lacking in about one third of the 60 research papers, while more than half lacked information on the stocking density (i.e. grazing pressure). More than one third of the studies did not provide information on seasonality of grazing and on the grazing method (Fig. 4). Among those that did, free-ranging was the most studied method of grazing, followed by fenced and exclosure studies, while there was only one study where animal movement was reportedly controlled by a herder (Zhang et al., 2009).

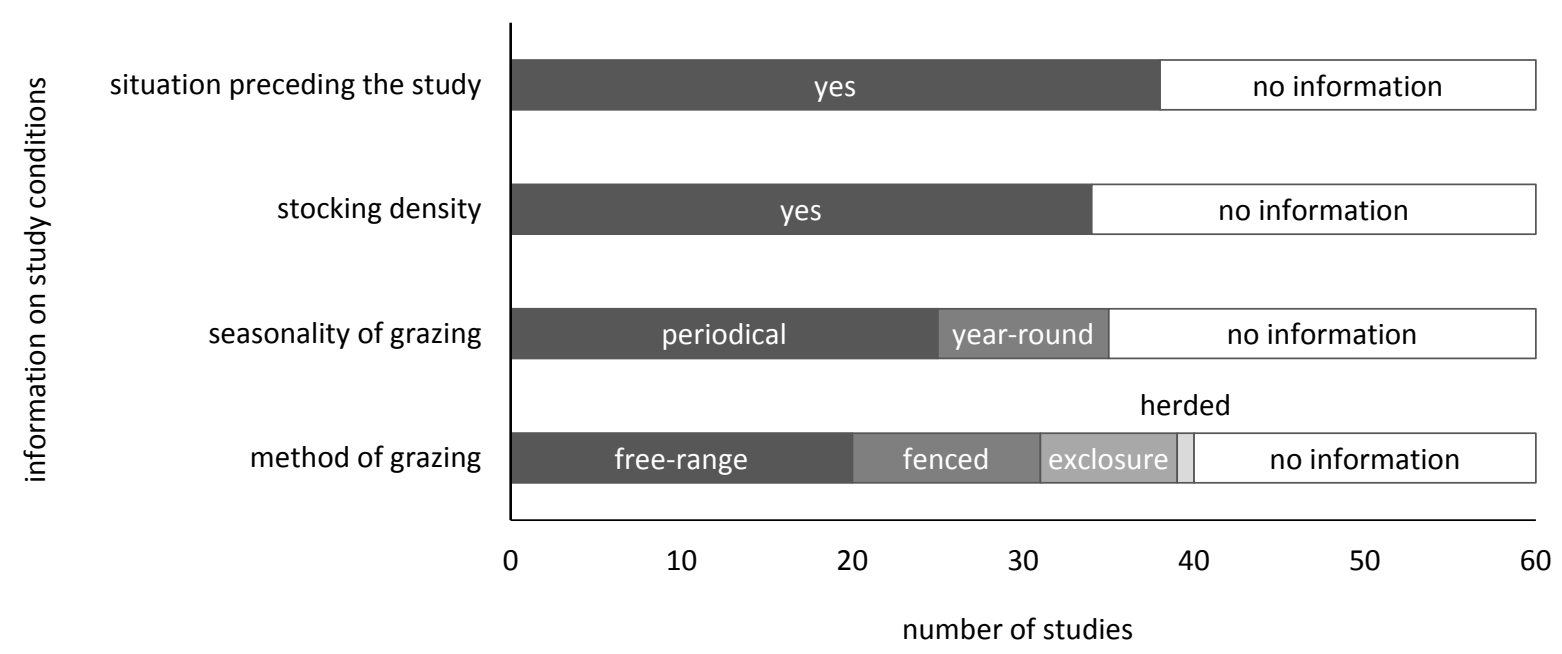

Fig. 4. Overview of the information provided and missing regarding the conditions of the analysed studies

\subsection{Overview of the impacts of grazing on composition and richness of forest elements}

Grazing affected forest elements in diverse ways, and the reported outcomes often differed among the reviewed studies (Fig. 5, Table 1, Table S1). There was a bias towards studies of the effects of grazing on the species composition of the herb layer (e.g. Darabant et al., 2007; Galleguillos et al., 2018). The most frequently reported outcome was that livestock grazing in forests decreases plant biomass, especially the regeneration and herb layer (e.g. Belsky and Blumenthal, 1997; Garin et al., 2000; McEvoy and McAdam, 2008). The opposite effect was also reported, though in fewer cases, especially for natural regeneration, but also for shrubs and bryophytes (e.g. Humphrey and Patterson, 2000; Galleguillos et al., 2018). Increase of invasive species biomass was reported by two studies (Smale et al., 2008; Galleguillos et al., 2018), while the opposite effect was reported by three studies (Chauchard et al., 2006; Mayerfeld et al., 2016; Mazzini et al., 2018).

Habitat heterogeneity, canopy species composition, invasive species or bryophytes were less studied (e.g. Thomason, 1995; Mayerfeld et al., 2016). Species composition changed in many studies (e.g. Dambach, 1944; Zhang et al., 2009), several studies assessing habitat heterogeneity reported an increase (e.g. Tubbs, 1997; Strandberg et al., 2005), referring to changed microsite attributes and seedling bank structure at plot or stand scale (e.g. Laskurain et al., 2013), or assessing forest dynamics and structure at landscape scale (Madany and West, 1983). Litter cover decreased, while the amount of bare soil increased in most cases (e.g. Mitchell \& Kirby, 1990; Laskurain et al., 2013). 


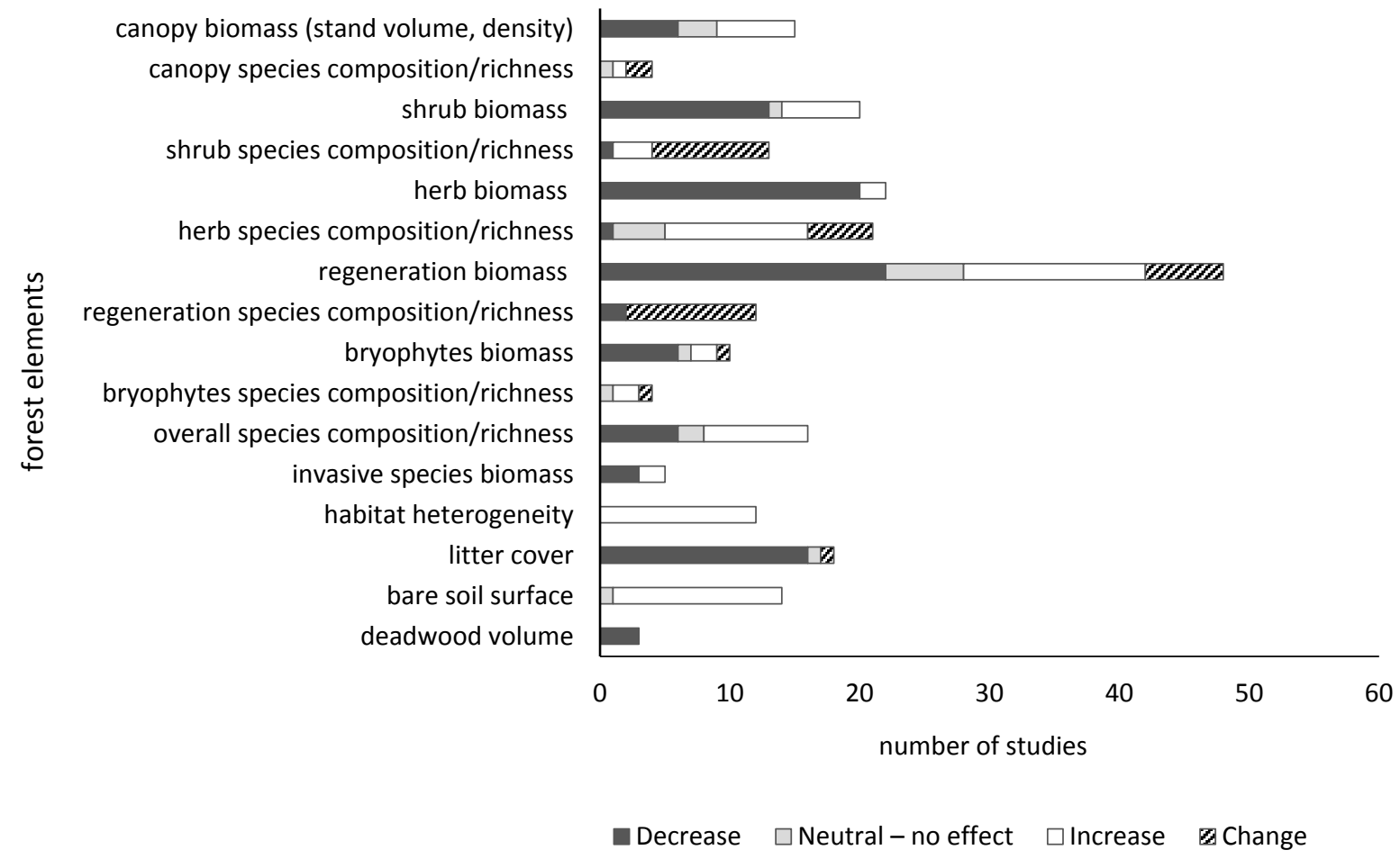

Fig. 5. Impacts of grazing by domestic livestock on forest elements

Table 1. Trends in livestock grazing effects at landscape scale and on various forest elements (increase: $\lambda$; decrease/reduction: $\searrow$; qualitative changes: $X$ ), and examples of the processes and mechanisms

\section{Effects on Trend General pattern for processes and mechanisms References}

\section{Landscape scale and overall vegetation}

Habitat

heterogeneity

and species

richness

Species $\quad \searrow$
richness

\section{Alteration of forest boundaries; modifying} microsite attributes (e.g. amount of bare soil, litter). Grazing livestock can change the seedling bank structure, thus affect the dynamics and structure of forest remnants. Forest grazing can result in higher floristic diversity, create niches and spatial heterogeneity for several species. Cattle grazing can increase species richness, particularly in the herb layer, though these effects can take several years to be expressed. Introduction of invasive weeds or non-native species, and suppression of grazing intolerant palatable and forest specialist species. Plants in grazed sites can be sparser and less vigorous. Seedling establishment, sapling recruitment and functional diversity can be greater in un-grazed than in grazed forests.
Kirby et al., 1994; Tubbs, 1997; Strandberg et al., 2005; Vanbergen et al., 2006; McEvoy et al., 2006a; Laskurain et al., 2013

Dambach, 1944; Norbu, 2002; Smale et al., 2008; Lindgren and Sullivan, 2012; Ford et al., 2018 


Ruderal and
thorny,
unpalatable
species

Canopy layer
Shaping the
appearance of
understorey
specimens

$\begin{aligned} & \text { Canopy } \\ & \text { openness }\end{aligned}$

Stand density/volume

$\begin{aligned} & \text { Stand density } \\ & \text { and timber } \\ & \text { volume }\end{aligned}$
$\begin{aligned} & \text { Timber } \\ & \text { volume }\end{aligned}$

Shrub layer

Shrub cover

Outcompeting $\searrow$ fast-growing shrub and tree species

Non-native $\quad y$ invasive species
Grazing tolerant species benefit from heavy grazing pressures, and introduction of species through zoochory. The understory of grazed forests can become dominated by unpalatable species, like the tall tussocky grass, Molinia caerulea.

Eating tree leaves; pollarding of trees for leaf fodder in winter, when grasses and other edible herbage are not available. Browsed branches of llex sp. had reduced leaf size and increased spinescence. Browsing also reduced understory height, leading to suppressed adult individuals.

Preventing the development of dense understorey (i.e. regeneration of existing canopy species) and favouring a transition from canopies of tall, long-lived trees to short, ephemeral ones. Reversing successional processes and litter decomposition rates in oak forests by maintaining the forest in a species rich open stage.

Reducing the competitive herb layer, helping the development of dense Pinus ponderosa forests. Grazing improved site conditions for tree regeneration (inhibitor vegetation control), leading to increased height and DBH of regenerating trees in grazed stands.

Increased openness can lead to reduced resilience of forest regeneration. Stand volume decreased exponentially with livestock density whereas biodiversity and forage cover showed a humped response function to livestock density. No differences between grazed and non-grazed woods in long term as regards growth rate or total ring width

Grazing and trampling (mainly cattle) and browsing (mainly goat and sheep) can lead to reduced shrub volumes and cover. Cattle had an impact both by direct consumption and by opening initially closed scrub.

Grazing and trampling (mainly cattle) and browsing (mainly goat and sheep). Cattle can inhibit the regeneration of non-native pines, impacting scrub development, both by direct consumption and by opening initially closed scrub, favouring timber species (e.g. Fagus sp.) against outcompeting trees and shrub.

Goats can destroy and eliminate unwanted shrubs. Cattle can inhibit the regeneration of black pine, which is recruiting naturally in areas where cattle are excluded. Farmers and
McEvoy et al., 2006a; Smale et al., 2008; Cooper and McCann, 2011; Ford et al., 2018; Galleguillos et al., 2018

Putman et al., 1987; Kirby et al., 1994; Garin et al., 2000; Norbu, 2002

Strandberg et al., 2005; Vanbergen et al., 2006; Konstantinidis et al., 2008; Smale et al., 2008

Madany \& West, 1983; Sharrow at al., 1992; Belsky and Blumenthal, 1997; Borman, 2005; Chauchard et al., 2006

Mitchell and Kirby, 1990; Noack et al., 2010

Cutter et al., 1998

Sharrow et al., 1992; Kirby et al., 1994; Lamoot et al., 2005; Zhang et al., 2009; Lindgren \& Sullivan, 2012; Mayerfeld et al., 2016 Nakashizuka \& Numata, 1982; Lamoot et al., 2005; Chauchard et al., 2006; Darabant et al., 2007; Cooper \& McCann, 2011

Chauchard et al., 2006; Mayerfeld et al., 2016 


Abundance of
light-
demanding,
poisonous,
thorny and
introduced
shrubs

Rubus spp. $\quad \searrow$ cover professionals acknowledged the potential of grazing in managing several invasive and opportunistic species (e.g. Rhamnus cathartica, Zanthoxylum americanum, Acer negundo). Increased light conditions following the reduction of the coverage of the upper canopy, favouring light-demanding species, like Crataegus spp., Malus sylvestris and Corylus avellana in the understorey, and oak in the canopy layer. When it is a long-term disturbance factor, grazing can lead to the increase of abundance of non-palatable, spiny, or grazing resistant shrubs, such as Juniperus oxycedrus or Quercus coccifera.

Grazing and trampling disturb thickets. Large herbivore grazing reduces the cover and height of Rubus spp., while removal of grazing results in significantly higher Rubus cover than in grazed areas.

$\begin{array}{ll}\text { Herb layer } & \\ \text { Species } & \nearrow \\ \text { richness and } & \\ \text { diversity } & \\ \text { Grass cover, } & \nearrow \\ \text { especially of } & \\ \text { grazing- } & \\ \text { adapted } \\ \text { species }\end{array}$

Abundance of $\searrow$ palatable $\quad$ species decreases and abundance of unpalatable species increases Lightdemanding and ruderal, and less forestspecialist species
Cattle grazing decreases the volume and slows the rate of competitive exclusion and increases herb richness and diversity in fertilized stands. Increasing light and reducing tall or competitive palatable species (e.g. Hyacinthoides nonscripta). In combination with active canopy management, cattle grazing can reduce shrub cover, favouring higher quality grass cover when forage production is a goal. Grazing can decrease the competitive dominance of the herbaceous layer, significantly reducing sward biomass. Sheep can be very effective in removing grass phytomass.

Selective forage and diverse palatability of herb layer species (e.g. high forage value plants are often good winter forage, like Hedera helix). Grazing has a negative impact on the palatable Hyacinthoides non-scripta. The abundance and/or frequency of species highly preferred by cattle, like Fagus orientalis seedlings or Vicia crocea is reduced.

Grazing changes species composition, leading to more species common in open pastures.

Exclosure from grazing reduces the abundance of light-dependent ruderals and increases the abundance of shade-tolerant forest species, changes being greater under a more developed tree canopy.
Emborg et al., 2000;

Konstantinidis et al., 2008; Smale, 2008;

Cooper \& McCann, 2011; Shakeri et al., 2012;

Galleguillos et al., 2018

Fitzgerald et al., 1986; Latham \& Blackstock, 1998; Garin et al. 2000; McEvoy et al., 2006a; Van Uytvanck \& Hoffmann, 2009; Cooper \& McCann, 2011; Shakeri et al., 2012

Lindgren and Sullivan, 2012

Kirby et al., 1994; McEvoy et al., 2006 a,b; Tasker \& Bradstock, 2006; Lesica, 2009; Cooper \& McCann, 2011; Galleguillos et al., 2018 Sharrow et al. 1992; Belsky and Blumenthal, 1997; Garin et al., 2000; McEvoy \& McAdam, 2008; Papachristou \& Platis, 2011

Madany \& West, 1983; Kirby et al., 1994; Garin et al., 2000; Fraser et al., 2001; Van Uytvanck \& Hoffmann, 2009; Shakeri et al., 2012

Dambach, 1944; Garin et al., 2000; McEvoy et al., 2006; Smale et al., 2008; Cooper and McCann, 2011 


\begin{tabular}{|c|c|c|c|}
\hline $\begin{array}{l}\text { Abundance of } \\
\text { ground- } \\
\text { growing } \\
\text { bryophytes }\end{array}$ & $\pi$ & $\begin{array}{l}\text { Heavy grazing reduces the competition from } \\
\text { vascular plants and accumulation of litter from } \\
\text { vascular plant and trees. }\end{array}$ & $\begin{array}{l}\text { Kirby et al., 1994; } \\
\text { Thomason, } 1995\end{array}$ \\
\hline $\begin{array}{l}\text { Bare soil } \\
\text { surface }\end{array}$ & $\pi$ & $\begin{array}{l}\text { Trampling and uprooting removes dead and live } \\
\text { plant materials from forest floor, leading to an } \\
\text { increase in bare soil cover. }\end{array}$ & $\begin{array}{l}\text { Mitchell \& Kirby, 1990; } \\
\text { Beymer and Klopatek, } \\
\text { 1992; Vanbergen et al., } \\
\text { 2006; Laskurain et al., } \\
\text { 2013; Galleguillos et al., } \\
2018\end{array}$ \\
\hline Deadwood & $\searrow$ & $\begin{array}{l}\text { Probably as an outcome of trampling, hooves } \\
\text { shredding the woody debris, thus speeding up } \\
\text { the rate of decomposition. }\end{array}$ & $\begin{array}{l}\text { Latham and Blackstock, } \\
\text { 1998; McEvoy et al., } \\
\text { 2006a; Smale et al., } 2008\end{array}$ \\
\hline Litter cover & $\searrow$ & $\begin{array}{l}\text { Trampling and grazing reduce the thickness of } \\
\text { the herb and regeneration layer. In a less dense } \\
\text { herb layer wind removes litter more easily. } \\
\text { Grazed forests have lower litter depth and } \\
\text { cover. }\end{array}$ & $\begin{array}{l}\text { Dambach, 1944; Belsky } \\
\text { and Blumenthal, 1997; } \\
\text { Bromham et al., 1999; } \\
\text { Latham \& Blackstock, } \\
\text { 1998; Humphrey and } \\
\text { Patterson, 2000; } \\
\text { Galleguillos et al., } 2018\end{array}$ \\
\hline $\begin{array}{l}\text { Non-native, } \\
\text { species } \\
\text { abundance } \\
\text { Regeneration }\end{array}$ & $\pi$ & $\begin{array}{l}\text { Introducing forest grazing into regions where it } \\
\text { was not traditionally practiced. }\end{array}$ & $\begin{array}{l}\text { Smale et al., 2008; } \\
\text { Galleguillos et al., } 2018\end{array}$ \\
\hline $\begin{array}{l}\text { Regeneration } \\
\text { survival rate }\end{array}$ & $\searrow$ & $\begin{array}{l}\text { Grazing and trampling causes injuries and plant } \\
\text { deaths, keeps the regeneration plants at low } \\
\text { height. In forests used for grazing Quercus had } \\
\text { limited regeneration. As a result of grazing, } \\
\text { sapling numbers are much lower than seedlings } \\
\text { numbers. }\end{array}$ & $\begin{array}{l}\text { Peterken and Tubbs, 1965; } \\
\text { Adams, 1975; Hester et } \\
\text { al., 1996; Chauchard et al., } \\
\text { 2006; Buffum et al., 2009; } \\
\text { Kaufmann et al., 2014; } \\
\text { Milios et al., 2014; Mazzini } \\
\text { et al., } 2018\end{array}$ \\
\hline $\begin{array}{l}\text { Seedling } \\
\text { height and/or } \\
\text { diameter }\end{array}$ & $\searrow$ & $\begin{array}{l}\text { Grazing or trampling of terminal buds/ leaders } \\
\text { prevent growth. Intensive grazing keeps the } \\
\text { regeneration plants at low height. }\end{array}$ & $\begin{array}{l}\text { Kingery \& Graham, 1991; } \\
\text { Fraser et al., 2001; } \\
\text { McEvoy et al., 2006b; } \\
\text { Milios et al., 2014; Schulze } \\
\text { et al., 2014; Rhodes et al., } \\
\text { 2018; }\end{array}$ \\
\hline $\begin{array}{l}\text { Seedling } \\
\text { survival and } \\
\text { growth }\end{array}$ & $\pi$ & $\begin{array}{l}\text { Removal of outcompeting vegetation creates } \\
\text { niches for regeneration. Grazing reduces the } \\
\text { competition between unwanted woody } \\
\text { vegetation and young conifers. Sustained heavy } \\
\text { grazing removes grass competition, permitting } \\
\text { the seedling trees to grow. }\end{array}$ & $\begin{array}{l}\text { Rummel, 1951; } \\
\text { Nakashizuka and Numata, } \\
\text { 1982; Mitchell and Kirby, } \\
\text { 1990; Sharrow et al., } \\
\text { 1992; Belsky and } \\
\text { Blumenthal, 1997; } \\
\text { Darabant et al., 2007; } \\
\text { McEvoy \& McAdam, } 2008\end{array}$ \\
\hline $\begin{array}{l}\text { Regeneration } \\
\text { of light- } \\
\text { demanding } \\
\text { tree species }\end{array}$ & $\pi$ & $\begin{array}{l}\text { Creating open niches by removing competitive } \\
\text { vegetation. Grazing enhances the hoarding } \\
\text { activities of small rodents, benefiting the early } \\
\text { seed-dispersal fitness of Quercus liaotungensis. }\end{array}$ & $\begin{array}{l}\text { Madany and West, 1983; } \\
\text { McEvoy et al., 2006b; } \\
\text { Zhang et al., 2009; } \\
\text { Shakeri et al., } 2012\end{array}$ \\
\hline
\end{tabular}




\subsection{Factors influencing the effects of grazing}

Livestock preferences and the characteristics of the forest affected the outcomes (Fig. 6, Table S2). For example, Garin et al. (2000) showed that sheep selected larch plantations which reduced damage to high conservation value oak (Quercus) and beech (Fagus) forests. Cattle preferred uncut forest sites instead of harvested sites, thus damage levels were insufficient to alter deciduous regeneration in plantations (Kaufmann et al., 2014).

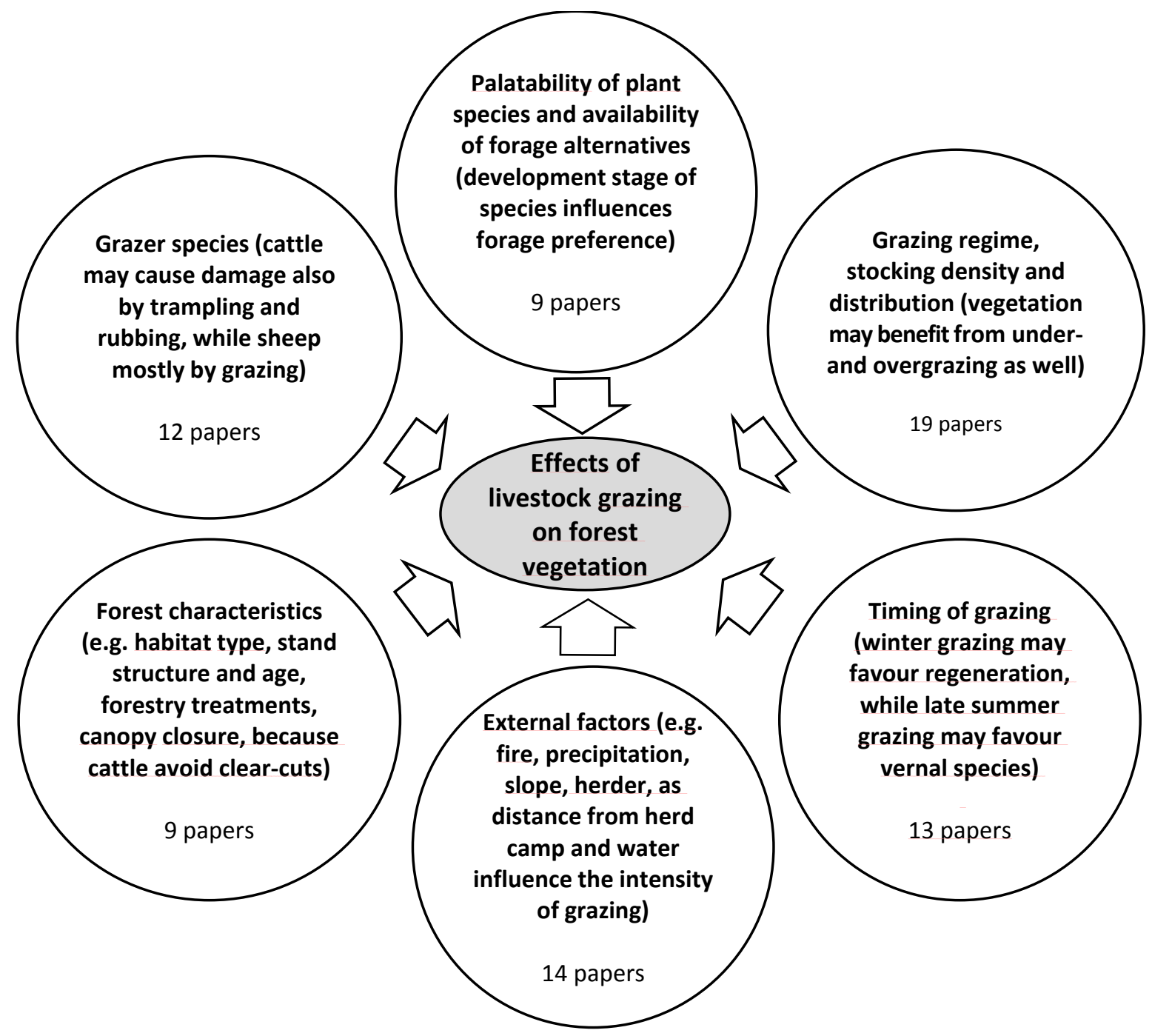

Fig. 6. The main biotic and abiotic factors that influence the effects of forest grazing by domestic livestock (with number of references stressing out each factor), based on the reviewed literature (see Table S2 for a complete list of references)

Seasonal variation in impacts were also observed. For example, snowberry (Symphoricarpos sp.) unpalatable in early season, became more acceptable later on, when alternative forage was unavailable (Fitzgerald et al., 1986). Cattle preferred the forest in spring and end of summer, and autumn (Mitchell and Rodgers, 1985; Lamoot et al., 2005; Papachristou and Platis, 2011), while goats preferred woody vegetation in spring (Papachristou \& Platis, 2011; Mayerfeld et al., 2016). Grazing, particularly in winter, may benefit early seedling growth by reducing competition from the ground vegetation, but once the saplings start to grow above the height of the surrounding vegetation, they are vulnerable to winter browsing (Kirby et al., 1994). Grazing at the end of the growing season had little effect on tree growth, thus being recommended as a silvicultural tool for removing competitive 
grasses in plantations (McEvoy and McAdam, 2008). Besides the differences in palatability between species (Kirby et al., 1994; Garin et al., 2000; Darabant et al., 2007), grazing preference also changes over time (Fitzgerald et al., 1986). Rubus spp. were one of the palatable species most targeted by deliberate grazing, which was shown to be most effective in spring (Van Uytvanck and Hoffmann, 2009).

Stocking level and grazing regime are important but have unpredictable effects on grazing impact. Heavy grazing was beneficial for certain species and groups, like small-seeded trees such as birch, that need bare soil as potential regeneration sites (Kirby et al., 1994).

Few studies dealt with external factors such as the role and management activity of the herders, who often have a deep knowledge and responsibility for the management of their grazing lands (Norbu, 2002). For example, planting and managing fodder trees by herders can improve forage resources and enhance tree species diversity (Fraser et al, 2001; McEvoy \& McAdam, 2008), influencing the stand structure and openness of forests (Norbu, 2002). Herding dogs also influence the effects of grazing on vegetation (Fraser et al., 2001). Livestock density decreased with distance from the herdsmen camp, influencing forage cover and plant diversity (Noack et al., 2010).

\subsection{Recommendations for (re-)integrating livestock grazing and forest management}

Forest grazing was recommended in some of the studies either as a silvicultural tool or for nature conservation purpose. The first category included cases of free-range grazing for the control of nonnative species, i.e. black pine (Pinus nigra) in a mixed deciduous forest (Chauchard et al., 2006); for promoting the regeneration of conifers (Darabant et al., 2007); and the application of mob-stocking with sheep for grass control in plantations (McEvoy and McAdam, 2008). Grazing with livestock was considered an effective nature conservation tool, i.e. it helped to create or maintain the desired habitat and species mixtures, in mixed deciduous (e.g. Lamoot et al., 2005; Strandberg et al., 2005; Fortuny et al., 2014) and mixed conifer forests (Lindgren and Sullivan, 2012), and particularly in UK forest studies (e.g. Mitchell \& Kirby, 1990; Kirby et al., 1994; McEvoy et al. 2006b). It was also recommended for maintaining open ground within conifer plantations that had been established on species-rich grasslands (Humphrey and Patterson, 2000).

Recommendations for future management varied among studies (Supporting information Table S3) and highlighted the importance of appropriate stocking levels and grazer species (Kirby et al., 1994; Fraser et al., 2001; Papachristou \& Platis, 2011), controlled, rotational or periodical grazing (Hester et al., 1996; McEvoy et al, 2006; Van Uytvanck \& Hoffmann, 2009) and flexibility in relation with herbage production and other site characteristics (Mitchell and Kirby, 1990; Thomason, 1995; Pollock et al., 2005; Galleguillos et al., 2018). Several articles stressed the importance of controlling overgrazing (Nakashizuka and Numata, 1982; Mitchell \& Kirby, 1990) and ensuring that the preferred woody species can grow to heights beyond the reach of animals (Papachristou and Platis, 2011; Kaufmann et al., 2014).

Complete exclusion of grazing might be likely to lead to dramatic changes in the structure and composition of forests (Kirby et al., 1994), including possible shifts in vegetation towards non-native species (Chauchard et al., 2006; Cooper and McCann, 2011). It was recommended only in situations of severe grazing (Dambach, 1944; Milios et al., 2014), in highly fragmented eucalypt forest remnants (Bromham et al., 1999) and in situations where livestock grazing was not part of the traditional forest management, as reported from a New Zealand conifer forest (Smale et al., 2008). Two other papers considered that closed canopy, high quality timber (commercial) forests should not be grazed, but acknowledged the potential for silvopastoral systems (Noack et al., 2010; Mayerfeld et al., 2016).

\section{Discussion}

Livestock grazing in temperate forests continues to be a major issue for managers and conservationists alike. Its complexity (Fitzgerald et al., 1986; Pollock et al., 2005; Kaufmann et al., 2013), diverse, largescale and long-lasting influence can make it difficult, however, to generalise with respect its various potential uses in vegetation management (Kirby et al. 1994; Bernes et al., 2018). 
The interpretation of the reviewed papers was often hampered by inadequate description of the study conditions. About one third of the research papers did not provide information about the land-use history and/or the situation preceding the study, and more than half lacked data about stocking density (i.e. grazing pressure). Studies lacking information on seasonality accounted for $42 \%$. The issue of seasonality of grazing may also bias results because grazing is often done in early spring or winter, but the vegetation is assessed during the growing season. Apart from the differences in palatability between species (Kirby et al., 1994; Garin et al., 2000; Darabant et al., 2007), grazing preference also changes over time, together with changes in the availability of forage alternatives and the character of species (e.g. taste, forage value, proportion of leaves; Fitzgerald et al., 1986; Jones et al. 2011).

\subsection{The complexity of impacts on vegetation}

Forest grazing is a kind of inhibitor disturbance, with seemingly obvious effects, though often generating apparently independent processes. Forest grazing acts on plants through removing/damaging them directly and favouring certain species by selectively removing its competitors (Nakashizuka and Numata, 1982; Belsky and Blumenthal, 1997; Borman, 2005; Darabant et al., 2007) and though changing the physical environment (particularly light and nutrient regimes), which together also then change the competitive balance between species (Dambach, 1944; Garin et al., 2000; McEvoy et al., 2006b; Smale et al., 2008). Most studies reported the obvious and expected effects, including the reduction of vegetation biomass or increase in the grass cover, especially of grazing-adapted species (Kirby et al., 1994; Galleguillos et al., 2018; Fig. 2; Table 1), at the expense of shade-tolerant and forest specialist species in the herb layer or increase in the abundance of lightdemanding and ruderal species (Dambach, 1944; Smale et al., 2008; Cooper and McCann, 2011).

Diversity of various species groups and features has been reported as both increasing and decreasing, but some of this difference might be due to methodological and/or scale bias. Most studies focus on stand/plot level effects for a short period of time, despite the fact that some effects (e.g. increase of floristic and structural diversity) can take several years to be expressed (see Table 1 for more mechanisms). At the plot or stand scale, habitat heterogeneity might decrease through the loss of litter (Belsky and Blumenthal, 1997; Bromham et al., 1999; Galleguillos et al., 2018), reduced understorey cover etc. (Strandberg et al., 2005; Vanbergen et al., 2006). However, at the landscape scale, if other areas are less grazed, heterogeneity might increase because there would now be mixture of high and low litter cover, open and closed understoreys etc. Grazing and trampling increases the amount of bare soil surface, compacting soils and influencing water infiltration rates, but also facilitates the burial of seeds and acorns, thus benefiting seedling establishment (Linhart and Whelan, 1980; Vanbergen et al. 2006; Laskurain et al. 2013). Livestock grazing can contribute to a decrease in the amount of deadwood, most probably through trampling (Latham and Blackstock, 1998; McEvoy et al., 2006a), change the character of forests, by inducing its development into dense monospecific stands, like the case of Pinus ponderosa forests (Belsky and Blumenthal, 1997), or benefit the early seed-dispersal of oak by facilitating acorn dispersal by small rodents (Zhang et al., 2009).

The significance of any impacts is affected by the landscape and historical context of the site, but these are often confounded. For example, slopes influence the vegetation composition as well as the movement and impact of livestock (Fortuny et al., 2014; Galleguillos et al., 2018). The presence or absence of forage alternatives, accessibility, distance from water and camp sites also influence the outcomes of grazing (Pollock et al., 2005; McEvoy and McAdam, 2008; Kaufmann et al., 2013). Landscape and historical factors may also affect the quality and quantity of the available forage at any time and hence interact with seasonality of grazing effects (Kirby et al., 1994; Garin et al., 2000; Darabant et al., 2007; Van Uytvanck \& Hoffmann, 2009).

\subsection{Revisiting what we expect from the forest and from grazing?}

Livestock grazing in forests has a long history, but in the last two centuries societal perceptions were that separation of grazing and forestry was a more efficient way of organising farm and forest production (Noack et al., 2010; Kardell, 2016; Nichiforel et al., 2018). This went alongside a change in 
people's vision of what a forest should be like and in the nature of preferred forest products, focussing more on timber (Ciesielski and Stereńczak, 2018). However, both forests and societal perceptions have continued to change (Kirby and Watkins, 2015; Rois-Díaz et al., 2018), which brings us to the need for re-evaluating and reconsidering livestock grazing in forests.

What was seen as 'damage' to the forest, for example preventing regeneration, keeping stands open, is now often seen as potential cost-effective tool for vegetation management (Fraser et al., 2001; Chauchard et al., 2006; McEvoy \& McAdam, 2008) that contributes to the maintenance and enhancement of biodiversity (Kirby et al., 1994; Pollock et al., 2005; Fortuny et al., 2014). Forest grazing can contribute to the survival of cultural traditions and the well-being of local communities involved in animal husbandry, without greatly affecting timber production (Norbu, 2002; Darabant et al., 2007; Buffum et al., 2009), therefore providing higher income from the same area of land (Kingery and Graham, 1991).

Tensions between worldviews and interests still exist. On the one hand, maintaining high abundance of a culturally keystone species, like the Bluebell (Hyacinthoides non-scripta) in the UK, might be seen as more beneficial than increasing botanical diversity through grazing (McEvoy et al., 2006a); livestock grazing in forests was viewed negatively by urban visitors in Colorado (Wallace et al., 1996). Nevertheless, in most cases nature conservation and promoting traditional forest grazing are mutually supportive, often because the species and assemblages we value have developed as part of this cultural landscape management (Poschlod, 2015).

\subsection{Improving the research and practice of livestock grazing in forests}

We propose the following recommendations to be considered in the planning of an improved research and management as response to the demands for more solid evidences:

- Future research needs to move on from simple comparisons of grazing vs. non-grazing situations (Kirby et al., 1994; Hester et al., 1996), to comparative, controlled and quantitative studies (Pollock et al., 2005; Noack et al., 2010; Mazzini et al., 2018; Fig. 3).

- Livestock behaviour should be better understood, and different activities, like grazing, browsing, trampling, dunging, rubbing against the trees should be separated when considering livestock effects (Mitchell \& Rodgers, 1985; Kirby et al., 1994; McEvoy \& McAdam, 2008; Popp and Scheibe, 2014).

- More use should be made of traditional ecological and land management knowledge held by traditional herders who are controlling the grazing activity on a daily basis (Fraser et al., 2001; Norbu, 2002; Zhang et al., 2009). Local herders and farmers could enhance the success of forest grazing activities by preventing damage (for example by taking the livestock out of the forest, since when the animals are satiated with the forage, or if it becomes limited, they start to harm the trees (McEvoy and McAdam, 2008).

- There should be full documentation of the study conditions as the situation preceding the study, site characteristics, description of timing, intensity, duration, type of grazing, use of additional fodder, etc. provide essential information for our understanding and interpretation of the outcomes, thus allowing the formulation of management recommendations (Borman, 2005; Pollock et al., 2005; Bernes et al. 2018). To improve management recommendations, and assess the results, defining stocking density is important, though impacts are determined by more than just animal numbers (Pollock et al., 2005).

- The negative view of forest grazing is partly the outcome of a mix up of the impacts of increased wild ungulate populations and livestock grazing (Kingery and Graham, 1991). Therefore, the impacts of wild and domestic grazers need to be properly separated, because (i) grazing and movement of livestock and wild ungulates can be different, thus having different effects on forest vegetation (Walker et al., 2015; Bernes et al., 2018; Cromsigt et al., 2018); and (ii) livestock are much easier to control (Hester et al. 1996; Fraser et al., 2001).

- Other activities taking place in the same area (e.g. forestry management) need to be assessed alongside the grazing impacts because there are likely to be interactions (Kaufmann et al., 2014). 
- The reviewed studies varied greatly in the employed grazing method, therefore it is not possible, and, most of all, not desirable to single out one method (i.e. length and season of grazing, stock density, type and breed of livestock). Experiments are needed to find the best management practices in individual forests using livestock, including novel forest ecosystems (e.g. plantations, new agroforestry systems), at both site and landscape scale. These might then be built into a decision support system such as the Woodland Grazing Toolbox (Scottish Forestry, https://scotland.forestry.gov.uk/woodland-grazing-toolbox).

\subsection{A future for livestock forest grazing in conservation and silviculture management}

Our review has established a range of potential benefits from maintaining existing forest grazing and for its careful reintroduction.

- Livestock grazing can be used to control or encourage the spread of forest to create landscapescale vegetation mosaics which have been shown to have high cultural and biodiversity values (Humphrey \& Patterson, 2000; McEvoy et al., 2006b; Mayerfeld et al., 2016; Galleguilos et al., 2018).

- Within woodland it may be used to favour desired vegetation structures and compositions for conservation and forestry reasons (Kirby et al., 1994; Darabant et al., 2007; Kaufmann et al., 2013; Fortuny et al., 2014).

- It has also found value as a silvicultural tool for supressing competitive herbaceous and woody species in plantations (Sharrow et al., 1992; McEvoy and McAdam, 2008), and in controlling invasive woody species (Chauchard et al., 2006; Mayerfeld et al., 2016).

- It can have an important role in fire mitigation, reducing the flammability of forests through reducing the combustible load of the forest understorey (McEvoy et al., 2006b, Varela et al., 2018), representing a potential management tool in the context of increasing incidence of extreme forest fires as an outcome of climate change.

- Forest grazing may also generate income for farmers through the sale of animals or meat, thus helping to support local livelihoods and communities (Kingery and Graham, 1991; Norbu, 2002, Rois-Díaz et al., 2018).

To enable us to fulfil the above potential more needs to be done to develop community-based research and knowledge co-production involving different stakeholder groups, such as foresters, herders, conservationists and stock owners (Wallace et al., 1996; Norbu, 2002; Mayerfeld et al., 2016). Researchers need to understand the social environment where forest grazing is taking place. There is the knowledge held by the international scientific community, as reflected by the methodology of our literature search, but also much practical knowledge is available in the grey literature (e.g. Humphrey et al., 1998; Mayle, 1999), which, with few exceptions (e.g. Bernes et al., 2018) is often overlooked by the scientific community. Also often overlooked is the traditional ecological knowledge that may not even make it into the grey literature. We must create space and openness for interdisciplinary and participatory approaches, to improve mutual learning and understanding between the various knowledge holders for developing effective conservation management methods.

The focus of research and conservation needs to be extended towards larger temporal and spatial scales, and shifted in the direction of more community-, evidence-based approaches in order to promote resilience of socio-ecological production forest landscapes. Grazing can be conducted in various ways, with just as numerous effects on vegetation, not all of which will be obvious from short term studies. Nonetheless, experiments are needed to provide the basis for harnessing the potential of livestock grazing in forests to deliver silvicultural and conservation benefits. At the same time we need to recover and learn from the historical meanings of forest grazing, and the effects of different types and regimes (such as pannage, free-range, herded, or mob-stocking, recognising the complex role of traditional herders and other people who manage grazing. We should reconsider our perception of forests and approaches and attitudes towards livestock in the forest, recognising traditional and local knowledge and reconnecting local people to their environment and natural resources (Norbu, 2002; Hartel and Plieninger, 2014). 


\section{Acknowledgement:}

Financial support was received from the National Research, Development and Innovation Office, Hungary [grant number NKFIH K 119478]. Further support was received from the Romanian Academy [grant number RO1567-IBB03/2019].

\section{References}

Adams, S.N., 1975. Sheep and cattle grazing in forests: A Review. J. Appl. Ecol. 12(1), 143-152. https://doi.org/10.2307/2401724

Belsky, A.J., Blumenthal, D.M., 1997. Effects of livestock grazing on stand dynamics and soils in upland forests of the interior West. Conserv. Biol. 11(2), 315-327. https://doi.org/10.1046/j.15231739.1997.95405.x

Bernes, C., Macura, B., Jonsson, B.G., Junninen, K., Müller, J., Sandström, J., ... Macdonald, E., 2018. Manipulating ungulate herbivory in temperate and boreal forests: effects on vegetation and invertebrates. A systematic review. Environmental Evidence 7, 13. https://doi.org/10.1186/s13750-018-0125-3

Beymer, R.J., Klopatek, J.M., 1992. Effects of grazing on cryptogamic crusts in Pinyon-Juniper woodlands in Grand Canyon National Park. Am. Midl. Nat. 127, 139-148. https://doi.org/10.2307/2426329

Borman, M.M., 2005. Forest stand dynamics and livestock grazing in historical context. Conserv. Biol. 19(5), 1658-1662. https://doi.org/10.1111/j.1523-1739.2005.00115.x

Bromham, L., Cardillo, M., Bennett, A.F., Elgar, M.A., 1999. Effects of stock grazing on the ground invertebrate fauna of woodland remnants. Aust. J. Ecol. 24, 199-207. https://doi.org/10.1046/j.1442-9993.1999.00963.x

Buffum, B., Gratzer, G., Tenzin, Y., 2009. Forest grazing and natural regeneration in a late successional broadleaved community forest in Bhutan. Mt. Res. Dev. 29(1), 30-35. https://doi.org/10.1659/mrd.991

Burrascano, S., Keeton, W.S., Sabatini, F.M., Blasi, C., 2013. Commonality and variability in the structural attributes of moist temperate old-growth forests: a global review. Forest Ecol. Manag. 291, 458-479. https://doi.org/10.1016/j.foreco.2012.11.020

Chauchard, S., Pille, G., Carcaillet, C., 2006. Large herbivores control the invasive potential of nonnative Austrian black pine in a mixed deciduous Mediterranean forest. Can. J. Forest Res. 36(4), 10471053. https://doi.org/10.1139/X05-282

Ciesielski, M., Stereńczak, K., 2018. What do we expect from forests? The European view of public demands. J. Environ. Manage. 209, 139-151. https://doi.org/10.1016/j.jenvman.2017.12.032

Cooper, A., McCann, T., 2011. Cattle exclosure and vegetation dynamics in an ancient, Irish wet oakwood. Plant Ecol. 212(1), 79-90. https://doi.org/10.1007/s11258-010-9805-y

Cromsigt, J.P.G.M., Kemp, Y.J.M., Rodriguez, E., Kivit, H., 2018. Rewilding Europe's large grazer community: how functionally diverse are the diets of European bison, cattle, and horses? Restor. Ecol. 26, 891-899. https://doi.org/10.1111/rec.12661

Cutter, B.E., Hunt, K., Haywood, J.D., 1998. Tree/wood quality in slash pine following long-term cattle grazing. Agroforest. Syst. 44, 305-312. https://doi.org/10.1023/A:1006219231801

Dambach, C.A., 1944. A ten-year ecological study of adjoining grazed and ungrazed woodlands in Northeastern Ohio. Ecol. Monogr. 14(3), 255-270. https://doi.org/10.2307/1948443

Darabant, A., Rai, P.B., Tenzin, K., Roder, W., Gratzer, G., 2007. Cattle grazing facilitates tree regeneration in a conifer forest with palatable bamboo understory. Forest Ecol. Manag. 252(13), 73-83. https://doi.org/10.1016/j.foreco.2007.06.018

Díaz, S., Demissew, S., Carabias, J., Joly, C., Lonsdale, M., Ash, N., ... Bartuska, A., 2015. The IPBES Conceptual Framework-connecting nature and people. Curr. Opin. Env. Sust. 14, 1-16. https://doi.org/10.1016/j.cosust.2014.11.002 
Emborg, J., Christensen, M., Heilmann-Clausen, J., 2000. The structural dynamics of Suserup Skov, a near-natural temperate deciduous forest in Denmark. Forest Ecol. Manag. 136, 173-189. https://doi.org/10.1016/S0378-1127(99)00094-8

ESRI (Environmental Systems Research Institute). 2012. ArcGIS.10.1. ESRI, Redlands, California.

Fitzgerald, R.D., Hudson, R.J., Bailey, A.W., 1986. Grazing preferences of cattle in regenerating aspen forest. J. Range Manage. 39(1), 13-18. https://doi.org/10.2307/3899677

Ford, H., Healey, J.R., Markesteijn, L., Smith, A.R., 2018. How does grazing management influence the functional diversity of oak woodland ecosystems? A plant trait approach. Agr. Ecosyst. Environ. 258, 154-161. https://doi.org/10.1016/j.agee.2018.02.025

Fortuny, X., Carcaillet, C., Chauchard, S., 2014. Land use legacies and site variables control the understorey plant communities in Mediterranean broadleaved forests. Agr. Ecosyst. Environ. 189, 53-59. https://doi.org/10.1016/j.agee.2014.03.012

Fortuny, X., Chauchard, S., Carcaillet, C., 2017. Confounding legacies of land uses and land-form pattern on the regional vegetation structure and diversity of Mediterranean montane forests. Forest Ecol. Manag., 384, 268-278. https://doi.org/10.1016/j.foreco.2016.11.002

Fraser, E.C., Kabzems, R., Lieffers, V.J., 2001. Sheep grazing for vegetation management in the northern forests of British Columbia and Alberta. Forest. Chron. 77(4), 713719. https://doi.org/10.5558/tfc77713-4

Galleguillos, N., Keeley, K., Ventura, S., 2018. Assessment of woodland grazing in southwest Wisconsin. Agr. Ecosyst. Environ. 260, 1-10. https://doi.org/10.1016/j.agee.2018.03.012

Garin, I., Aldezabal, A., Herrero, J., Garcia-Serrano, A., 2000. Understorey foraging and habitat selection by sheep in mixed Atlantic woodland. J. Veg. Sci. 11(6), 863-870. https://doi.org/10.2307/3236556

Gill, R.M.A., 1992. A review of damage by mammals in north temperate forests: 3 . impact on trees and forests. Forestry 65, 363-388. https://doi.org/10.1093/forestry/65.4.363-a

Graham, R.T., Jain, T.B., Kingery, J.L., 2010. Ameliorating conflicts among deer, elk, cattle and/or other ungulates and other forest uses: a synthesis. Forestry 83(3), 245-255. https://doi.org/10.1093/forestry/cpq003

Hartel, T., Plieninger, T. (Eds.), 2014. European wood-pastures in transition: a social-ecological approach. Routledge, Taylor and Francis Group, Abingdon, Oxon.

Hester, A.J., Mitchell, F.J.G., Kirby, K.J., 1996. Effects of season and intensity of sheep grazing on tree regeneration in a British upland woodland. Forest Ecol. Manag. 88, 99-106. https://doi.org/10.1016/S0378-1127(96)03815-7.

Humphrey, J., Gill, R., Claridge, J., 1998. Grazing as a management tool in European forest ecosystems. Forestry Commission Technical Paper 25. ISBN 0855383550.

Humphrey, J.W., Patterson, G.S., 2000. Effects of late summer cattle grazing on the diversity ofriparian pasture vegetation in an upland conifer forest. J. Appl. Ecol. 37, 986-996. https://doi.org/10.1046/j.1365-2664.2000.00550.x

Jones, B.E., Lile, D.F., Tate, K.W., 2011. Cattle selection for aspen and meadow vegetation: implications for restoration. Rangeland Ecol. Managem., 64(6): 625-632. https://doi.org/10.2111/REM-D10-00089.1

Kardell, O., 2016. Swedish forestry, forest pasture grazing by livestock, and game browsing pressure $\begin{array}{llll}\text { since } 1900 . & \text { Environ. }\end{array}$ https://doi.org/10.3197/096734016X14727286515817

Kaufmann, J., Bork, E. W., Alexander, M.J., Blenis, P.V., 2013. Habitat selection by cattle in Foothill landscapes following variable harvest of aspen forest. Forest Ecol. Manag. 306, 15-22. https://doi.org/10.1016/i.foreco.2013.06.004

Kaufmann, J., Bork, E.W., Alexander, M.J., Blenis, P.V., 2014. Effects of open-range cattle grazing on deciduous tree regeneration, damage, and mortality following patch logging. Can. J. Forest Res. 44(7), 777-783. https://doi.org/10.1139/cjfr-2014-0131

Kingery, J.L., Graham, R.T., 1991. The effect of cattle grazing on ponderosa pine regeneration. Forest. Chron. 67(3), 245-248. https://doi.org/10.5558/tfc67245-3 
Kirby, K.J., Mitchell, F.J., Hester, A.J., 1994. A role for large herbivores (deer and domestic stock) in nature conservation management in British seminatural woodlands. Arboricultural Journal 18(4), 381-399. https://doi.org/10.1080/03071375.1994.9747043

Kirby, K., Watkins, C. (Eds.), 2015. Europe's changing woods and forests: from wildwood to managed landscapes. CABI Publishing, Wallingford UK, Boston.

Konstantinidis, P., Tsiourlis, G., Xofis, P., Buckley, G.P., 2008. Taxonomy and ecology of Castanea sativa Mill. forests in Greece. Plant Ecol. 195, 235-256. https://doi.org/10.1007/s11258-007-9323-8

Lamoot, I., Meert, C., Hoffmann, M., 2005. Habitat use of ponies and cattle foraging together in a coastal dune area. Biol. Conserv. 122(4), 523-536. https://doi.org/10.1016/i.biocon.2004.09.009

Laskurain, N.A., Aldezabal, A., Olano, J.M., Loidi, J., Escudero, A., 2013. Intensification of domestic ungulate grazing delays secondary forest succession: evidence from exclosure plots. J. Veg. Sci. 24(2), 320-331. https://doi.org/10.1111/j.1654-1103.2012.01469.x

Latham, J., Blackstock, T.H., 1998. Effects of livestock exclusion on the ground flora and regeneration of an upland Alnus glutinosa woodland. Forestry 71(3), 191-197. https://doi.org/10.1093/forestry/71.3.191

Lesica, P., 2009. Can regeneration of green ash (Fraxinus pennsylvanica) be restored in declining woodlands in Eastern Montana? Rangeland Ecol. Manag. 62, 564-571. https://doi.org/10.2111/.1/REM-D-09-00020.1

Lindgren, P.M.F., Sullivan, T.P., 2012. Response of plant community abundance and diversity during 10 years of cattle exclusion within silvopasture systems. Can. J. Forest Res. 42(3), 451-462. https://doi.org/10.1139/X2012-003

Linhart, Y.B., Whelan, RJ., 1980. Woodland regeneration in relation to grazing and fencing in CoedGorswen, North Wales. J. Appl. Ecol., 17(3), 827-840. https://doi.org/10.2307/2402659

Madany, M.H, West, N.E., 1983. Livestock grazing-fire regime interactions within montane forests of Zion National Park, Utah. Ecology 64, 661-667. https://doi.org/10.2307/1937186

Mayerfeld, D., Rickenbach, M., Rissman, A., 2016. Overcoming history: attitudes of resource professionals and farmers toward silvopasture in southwest Wisconsin. Agroforest. Syst. 90(5), 723-736. https://doi.org/10.1007/s10457-016-9954-7

Mayle, B., 1999. Domestic stock grazing to enhance woodland biodiversity. Forestry Commission, 12 p. ISBN 0-85538-504-9.

Mazzini, F., Relva, M.A., Malizia, L.R., 2018. Impacts of domestic cattle on forest and woody ecosystems in southern South America. Plant Ecol. 219(8), 913-925. https://doi.org/10.1007/s11258-018$\underline{0846-y}$

McEvoy, P.M., Flexen, M., McAdam, J.H., 2006. The effects of livestock grazing on ground flora in broadleaf woodlands in Northern Ireland. Forest Ecol. Manag. 225, 39-50. https://doi.org/10.1016/j.foreco.2005.12.026

McEvoy, P.M., McAdam, J.H., Mosquera-Losada, M., Rigueiro-Rodriguez, A., 2006. Tree regeneration and sapling damage of pedunculate oak Quercus robur in a grazed forest in Galicia, NW Spain: a comparison of continuous and rotational grazing systems. Agroforest. Syst. 66(2), 85-92. https://doi.org/10.1007/s10457-005-2916-0

McEvoy, P.M., McAdam, J.H., 2008. Sheep grazing in young oak Quercus spp. and ash Fraxinus excelsior plantations: vegetation control, seasonality and tree damage. Agroforest. Syst. 74, 199-211. https://doi.org/10.1007/s10457-008-9121-x

Milios, E., Pipinis, E., Kitikidou, K., Batziou, M., Chatzakis, S., Akritidou, S., 2014. Are sprouts the dominant form of regeneration in a lowland Quercus pubescens-Quercus frainetto remnant forest in Northeastern Greece? A regeneration analysis in the context of grazing. New Forests 45(2), 165-177. https://doi.org/10.1007/s11056-013-9399-z

Mitchell, F.J.G., 2005. How open were European forests? Hypothesis testing using palaeoecological data. J. Ecol. 93, 168-177. https://doi.org/10.1111/i.1365-2745.2004.00964.x

Mitchell, F.J.G., Kirby, K.J., 1990. The impact of large herbivores conservation of semi-natural woods British uplands. Forestry 63(4), 333-353. https://doi.org/10.1093/forestry/63.4.333 
Mitchell, J.E., Rodgers, R.T., 1985. Food-habits and distribution of cattle on a forest and pasture range in Northern Idaho. J. Range Manage. 38(3), 214-220. https://doi.org/10.2307/3898969

Mosquera-Losada, M.R., Rigueiro Rodriguez, A., McAdam, J., 2005. Silvopastoralism and sustainable land management. CABI Publishing, Wallingford UK, Cambridge MA.

Nakashizuka, T., Numata, M., 1982. Regeneration process of climax beech forests II. Structure of a forest under the influences of grazing. Japan J. Ecol. 32, 473-482.

Nichiforel, L., Keary, K., Deuffic, P., Weiss, G., Thorsen, B.J., Winkel, G., ... Mifsud, E.G., 2018. How private are Europe's private forests? A comparative property rights analysis. Land Use Policy 76, 535-552. https://doi.org/10.1016/j.landusepol.2018.02.034

Noack, F.A.W., Manthey, M., Ruitenbeek, J.H., Mohadjer, M.R.M., 2010. Separate or mixed production of timber, livestock and biodiversity in the Caspian Forest. Ecol. Econ. 70(1): 67-76. https://doi.org/10.1016/j.ecolecon.2010.07.033

Norbu, L., 2002. Grazing management in broadleaf forests - Bhutan. J. Bhutan Studies 7, 99-129.

Olson, D.M., Dinerstein, E., Wikramanayake, E.D., Burgess, N.D., Powell, G.V.N., Underwood, E.C., ... Kassem, K.R., 2001. Terrestrial ecoregions of the world: a new map of life on Earth. BioScience 51(11), 933-938. https://doi.org/10.1641/0006-3568(2001)051[0933:TEOTWA]2.0.C0;2

Papachristou, T.G., Platis, P.D., 2011. The impact of cattle and goats grazing on vegetation in oak stands of varying coppicing age. Acta Oecol. 37(1), 16-22. https://doi.org/10.1016/j.actao.2010.11.001

Peterken, G.F., Tubbs, C.R., 1965. Woodland regeneration in the New Forest, Hampshire, since 1651. J. Appl. Ecol., 2(1), 159-170. https://doi.org/10.2307/2401702

Poschlod, P., 2015. Geschichte der Kulturlandschaft. Ulmer Verlag, Stuttgart.

Pollock, M.L., Milner, J.M., Waterhouse, A., Holland, J.P., Legg, C.J., 2005. Impacts of livestock in regenerating upland birch woodlands in Scotland. Biol. Conserv. 123(4), 443-452. https://doi.org/10.1016/j.biocon.2005.01.006

Popp, A., Scheibe, K.M., 2014. The ecological influence of large herbivores behavior - and habitat utilization of cattle and horses. Appl. Ecol. Env. Res., 12(3), 681-693. https://doi.org/10.15666/aeer/1203 68169

Putman, R.J., Pratt, R.M., Ekins, J.R., Edwards, P.J., 1987. Food and feeding behaviour of cattle and ponies in the New Forest, Hampshire. J. Appl. Ecol. 24, 369-380. https://doi.org/10.2307/2403881

Putman, R.J., 1996. Ungulates in temperate forest ecosystems: perspectives and recommendations for future research. Forest Ecol. Manag. 88(1-2), 205-214. https://doi.org/10.1016/S0378$1127(96) 03878-9$

Ramirez, J.I., Jansen, P.A., Poorter, L., 2018. Effects of wild ungulates on the regeneration, structure and functioning of temperate forests: A semi-quantitative review. Forest Ecol. Manag. 424, 406419. https://doi.org/10.1016/j.foreco.2018.05.016

Rackham, O., 1980. Ancient woodland: its history, vegetation and uses in England. Edward Arnold, London.

Rhodes, A.C., Larsen, R.T., Clair, S.B.S., 2018. Differential effects of cattle, mule deer, and elk herbivory on aspen forest regeneration and recruitment. Forest Ecol. Manag. 422, 273-280. https://doi.org/10.1016/j.foreco.2018.04.013

Rois-Díaz, M., Lovric, N., Lovric, M., Ferreiro-Domínguez, N., Mosquera-Losada, M.R., den Herder, M., ... Smith, J., 2018. Farmers' reasoning behind the uptake of agroforestry practices: evidence from multiple case-studies across Europe. Agroforest. Syst. 92(4), 811-828. https://doi.org/10.1007/s10457-017-0139-9

Rotherham, I.D. (Ed.), 2013. Trees, forested landscapes and grazing animals: A European perspective on woodlands and grazed treescapes. Routledge, Abingdon Oxon.

Rummell, R.S., 1951. Some effects of livestock grazing on ponderosa pine forest and range in central Washington. Ecology 32, 594-607. https://doi.org/10.2307/1932728

Samojlik, T., Fedotova, A., \& Kuijper, D.P.J., 2016. Transition from traditional to modern forest management shaped the spatial extent of cattle pasturing in Białowieża Primeval Forest in the 
nineteenth and twentieth centuries. Ambio 45(8), 904-918. https://doi.org/10.1007/s13280016-0795-4

Schulze, E.D., Bouriaud, O., Waldchen, J., Eisenhauer, N., Walentowski, H., Seele, C., ... Teodosiu, M., 2014. Ungulate browsing causes species loss in deciduous forests independent of community dynamics and silvicultural management in Central and Southeastern Europe. Ann. For. Res. 57, 267-288. https://doi.org/10.15287/afr.2014.273

Scottish Forestry. Woodland Grazing Toolbox. A guide to deciding what sort of grazing best suits your woodland. https://scotland.forestry.gov.uk/woodland-grazing-toolbox [last accessed on 17.05.2019]

Shakeri, Z., Mohadjer, M.R.M., Simberloff, D., Etemad, V., Assadi, M., Donath, T.W., ... Eckstein, R.L., 2012. Plant community composition and disturbance in Caspian Fagus orientalis forests: which are the main driving factors? Phytocoenologia 41(4), 247-263. https://doi.org/10.1127/0340269X/2011/0041-0513

Sharrow, S.H., Leininger, W.C., Osman, K.A., 1992. Sheep grazing effects on coastal Douglas fir forest growth: a ten-year perspective. Forest Ecol. Manag. 50(1-2), 75-85. https://doi.org/10.1016/0378-1127(92)90315-Z

Smale, M.C., Dodd, M.B., Burns, B.R., Power, I.L., 2008. Long-term impacts of grazing on indigenous forest remnants on North Island hill country, New Zealand. New Zeal. J. Ecol. 32(1): 57-66.

Smit, C., Ruifrok, J.L., van Klink, R., Olff, H., 2015. Rewilding with large herbivores: The importance of grazing refuges for sapling establishment and wood-pasture formation. Biol. Conserv. 182, 134142. https://doi.org/10.1016/j.biocon.2014.11.047

Strandberg, B., Kristiansen, S.M., Tybirk, K., 2005. Dynamic oak-scrub to forest succession: Effects of management on understorey vegetation, humus forms and soils. Forest Ecol. Manag. 211 (3) 318-328. https://doi.org/10.1016/j.foreco.2005.02.051

Tasker, E.M., Bradstock, R.A., 2006. Influence of cattle grazing practices on forest understorey structure in north-eastern New South Wales. Austral Ecol. 31, 490-502. https://doi.org/10.1111/j.1442-9993.2006.01597.x

Thomason, D., 1995. Grazing in western sessile oakwoods in the Lake District. Biol. J. Linn. Soc. 56(Suppl.), 49-51. https://doi.org/10.1111/j.1095-8312.1995.tb01119.x

Tubbs, C.R., 1997. The ecology of pastoralism in the New Forest. British Wildlife, 9(1), 7-16.

Vanbergen, A.J., Hails, R.S., Watt, A.D., Jones, T.H., 2006. Consequences for host-parasitoid interactions of grazing-dependent habitat heterogeneity. J. Anim. Ecol. 75(3), 789-801. https://doi.org/10.1111/j.1365-2656.2006.1099.x

Van Uytvanck, J., Hoffmann, M., 2009. Impact of grazing management with large herbivores on forest ground flora and bramble understorey. Acta Oecol. 35(4), 523-532. https://doi.org/10.1016/j.actao.2009.04.001

Varela, E., Górriz-Mifsud, E., Ruiz-Mirazo, J., López-i-Gelats, F., 2018. Payment for targeted grazing: integrating local shepherds into wildfire prevention. Forests 9(8), 464. https://doi.org/10.3390/ 90080464

Vera, F.W.M., 2000. Grazing Ecology and Forest History. CABI Publishing, Wallingford Oxon, New York.

Walker, S.C., Anderson, V.J., Fugal, R.A., 2015. Big game and cattle influence on aspen community regeneration following prescribed fire. Rangeland Ecol. Manag. 68(4), 354-358. https://doi.org/10.1016/j.rama.2015.05.005

Wallace, G.N., Mitchell, J.E., Wells, M.D., 1996. Visitor perceptions about grazing on a forest service cattle allotment. J. Range Manage. 49(1), 81-86. https://doi.org/10.2307/4002730

Zhang, H.M., Wang, Y., Zhang, Z.B., 2009. Domestic goat grazing disturbance enhances tree seed removal and caching by small rodents in a warm-temperate deciduous forest in China. Wildlife Res. 36(7), 610-616. https://doi.org/10.1071/WR09001 
Supporting information 1 - List of the 71 titles considered in the review

Supporting information 2 - Fig. S1. Location of the studies considered in the review and the major forest categories where these studies have been conducted

Supporting information 3 - Fig. S2. The cumulative number of the 71 publications included in the review, addressing the issue of domestic livestock grazing in temperate forests

Supporting information 4 - Table S1. Impacts of livestock grazing on forest elements

Supporting information $\mathbf{5}$ - Table S2. The main biotic and abiotic factors that influence the effects of livestock grazing in forests

Supporting information 6 -Table S3. Practical recommendations for the management of livestock grazing in temperate forests 


\section{Supporting information S1}

\section{List of the $\mathbf{7 1}$ titles considered in the review}

Adams, SN. 1975. Sheep and cattle grazing in forests: A Review. Journal of Applied Ecology, 12(1), 143152. doi: $10.2307 / 2401724$

Belsky, AJ; Blumenthal, DM. 1997. Effects of livestock grazing on stand dynamics and soils in upland forests of the interior West. Conservation Biology, 11(2), 315-327. doi: 10.1046/j.15231739.1997.95405.x

Beymer, RJ; Klopatek, JM. 1992. Effects of grazing on cryptogamic crusts in Pinyon-Juniper woodlands in Grand Canyon National Park. American Midland Naturalist, 127(1), 139-148. doi: $10.2307 / 2426329$

Borman, MM. 2005. Forest stand dynamics and livestock grazing in historical context. Conservation Biology, 19(5), 1658-1662. doi: 10.1111/j.1523-1739.2005.00115.x

Bromham, L; Cardillo, M; Bennett, AF; Elgar, MA. 1999. Effects of stock grazing on the ground invertebrate fauna of woodland remnants. Australian Journal of Ecology, 24(3), 199-207. doi: 10.1046/j.1442-9993.1999.00963.x

Buffum, B; Gratzer, G; Tenzin, Y. 2009. Forest grazing and natural regeneration in a late successional broadleaved community forest in Bhutan. Mountain Research and Development, 29(1), 30-35. doi: 10.1659/mrd.991

Chauchard, S; Pille, G; Carcaillet, C. 2006. Large herbivores control the invasive potential of nonnative Austrian black pine in a mixed deciduous Mediterranean forest. Canadian Journal of Forest Research, 36(4), 1047-1053. doi: 10.1139/X05-282

Cooper, A; McCann, T. 2011. Cattle exclosure and vegetation dynamics in an ancient, Irish wet oakwood. Plant Ecology, 212(1), 79-90. doi: 10.1007/s11258-010-9805-y

Cutter, BE; Hunt, K; Haywood, JD. 1998. Tree/wood quality in slash pine following long-term cattle grazing. Agroforestry Systems, 44, 305-312. doi: 10.1023/A:1006219231801

Dambach, CA. 1944. A Ten-Year Ecological study of adjoining grazed and ungrazed woodlands in Northeastern Ohio. Ecological Monographs, 14(3), 255-270. doi: 10.2307/1948443

Darabant, A; Rai, PB; Tenzin, K; Roder, W; Gratzer, G. 2007. Cattle grazing facilitates tree regeneration in a conifer forest with palatable bamboo understory. Forest Ecology and Management, 252(13), 73-83. doi: 10.1016/j.foreco.2007.06.018

Emborg, J; Christensen, M; Heilmann-Clausen, J. 2000. The structural dynamics of Suserup Skov, a nearnatural temperate deciduous forest in Denmark. Forest Ecology and Management, 126(2), 173189. doi: 10.1016/S0378-1127(99)00094-8

Epple, C. 2001. A vegetation study in the walnut and fruit-tree forests of Southern Kyrgyzstan. Phytocoenologia, 31(4), 571-604. doi: 10.1127/phyto/31/2001/571

Feldhake, CM; Neel, JPS; Belesky, DP. 2010. Establishment and production from thinned mature deciduous-forest silvopastures in Appalachia. Agroforestry Systems, 79(1), 31-37. doi: 10.1007/s10457-010-9289-8

Fitzgerald, RD; Hudson, RJ; Bailey, AW. 1986. Grazing preferences of cattle in regenerating aspen forest. Journal of Range Management, 39(1), 13-18. doi: 10.2307/3899677

Ford, H; Healey, JR; Markesteijn, L; Smith, AR. 2018. How does grazing management influence the functional diversity of oak woodland ecosystems? A plant trait approach. Agriculture Ecosystems and Environment, 258, 154-161. doi: 10.1016/j.agee.2018.02.025

Fortuny, X; Carcaillet, C; Chauchard, S. 2014. Land use legacies and site variables control the understorey plant communities in Mediterranean broadleaved forests. Agriculture Ecosystems and Environment, 189, 53-59. doi: 10.1016/j.agee.2014.03.012

Fortuny, X; Chauchard, S; Carcaillet, C. 2017. Confounding legacies of land uses and land-form pattern on the regional vegetation structure and diversity of Mediterranean montane forests. Forest Ecology and Management, 384, 268-278. doi: 10.1016/j.foreco.2016.11.002 
Fraser, EC; Kabzems, R; Lieffers, VJ. 2001. Sheep grazing for vegetation management in the northern forests of British Columbia and Alberta. The Forestry Chronicle, 77(4), 713719. doi: 10.5558/tfc77713-4

Galleguillos, N; Keeley, K; Ventura, S. 2018. Assessment of woodland grazing in southwest Wisconsin. Agriculture Ecosystems and Environment, 260, 1-10. doi: 10.1016/j.agee.2018.03.012

Garin, I; Aldezabal, A; Herrero, J; Garcia-Serrano, A. 2000. Understorey foraging and habitat selection by sheep in mixed Atlantic woodland. Journal of Vegetation Science, 11(6), 863-870. doi: $10.2307 / 3236556$

Hester, AJ; Mitchell, FJG; Kirby, KJ. 1996. Effects of season and intensity of sheep grazing on tree regeneration in a British upland woodland. Forest Ecology and Management, 88, 99-106. doi: 10.1016/S0378-1127(96)03815-7

Humphrey, JW; Patterson, GS. 2000. Effects of late summer cattle grazing on the diversity of riparian pasture vegetation in an upland conifer forest. Journal of Applied Ecology 37, 986-996. doi: 10.1046/j.1365-2664.2000.00550.x

Jones, BE; Lile, DF; Tate, KW. 2011. Cattle selection for aspen and meadow vegetation: implications for restoration. Rangeland Ecology and Management, 64(6): 625-632. doi: 10.2111/REM-D-1000089.1

Kardell, O. 2016. Swedish forestry, forest pasture grazing by livestock, and game browsing pressure since 1900. Environment and History, 22(4), 561-587. doi: 10.3197/096734016X14727286515817

Kaufmann, J; Bork, EW; Alexander, MJ; Blenis, PV. 2013. Habitat selection by cattle in Foothill landscapes following variable harvest of aspen forest. Forest Ecology and Management, 306, 15-22. doi: 10.1016/j.foreco.2013.06.004

Kaufmann, J; Bork, EW; Alexander, MJ; Blenis, PV. 2014. Effects of open-range cattle grazing on deciduous tree regeneration, damage, and mortality following patch logging. Canadian Journal of Forest Research, 44(7), 777-783. doi: 10.1139/cjfr-2014-0131

Kingery, JL; Graham, RT. 1991. The effect of cattle grazing on ponderosa pine regeneration. Forestry Chronicle, 67(3), 245-248. doi: 10.5558/tfc67245-3

Kirby, KJ; Mitchell, FJ, Hester, AJ. 1994. A role for large herbivores (deer and domestic stock) in nature conservation management in British seminatural woodlands. Arboricultural Journal. The International Journal of Urban Forestry, 18(4), 381-399. doi: 10.1080/03071375.1994.9747043

Konstantinidis, P; Tsiourlis, G; Xofis, P; Buckley, GP. 2008. Taxonomy and ecology of Castanea sativa Mill. forests in Greece. Plant Ecology, 195(2), 235-256. doi: 10.1007/s11258-007-9323-8

Lamoot, I; Meert, C; Hoffmann, M. 2005. Habitat use of ponies and cattle foraging together in a coastal dune area. Biological Conservation, 122(4), 523-536. doi: 10.1016/j.biocon.2004.09.009

Laskurain, NA; Aldezabal, A; Olano, JM; Loidi, J; Escudero, A. 2013. Intensification of domestic ungulate grazing delays secondary forest succession: evidence from exclosure plots. Journal of Vegetation Science, 24(2), 320-331. doi: 10.1111/j.1654-1103.2012.01469.x

Latham, J; Blackstock, TH. 1998. Effects of livestock exclusion on the ground flora and regeneration of an upland Alnus glutinosa woodland. Forestry, 71(3), 191-197. doi: 10.1093/forestry/71.3.191

Lesica, P. 2009. Can regeneration of green ash (Fraxinus pennsylvanica) be restored in declining Woodlands in Eastern Montana? Rangeland Ecology and Management, 62(6), 564-571. doi: 10.2111/.1/REM-D-09-00020.1

Lindgren, PMF; Sullivan, TP. 2012. Response of plant community abundance and diversity during 10 years of cattle exclusion within silvopasture systems. Canadian Journal of Forest Research, 42(3), 451-462. doi: 10.1139/X2012-003

Linhart, YB; Whelan, RJ. 1980. Woodland regeneration in relation to grazing and fencing in CoedGorswen, North Wales. Journal of Applied Ecology, 17(3), 827-840. doi: 10.2307/2402659

Madany, MH; West, NE. 1983. Livestock grazing-fire regime interactions within montane forests of Zion National Park, Utah. Ecology, 64(4), 661-667. doi: 10.2307/1937186 
Mayerfeld, D; Rickenbach, M; Rissman, A. 2016. Overcoming history: attitudes of resource professionals and farmers toward silvopasture in southwest Wisconsin. Agroforestry Systems, 90(5), 723-736. doi: 10.1007/s10457-016-9954-7

Mazzini, F; Relva, MA; Malizia, LR. 2018. Impacts of domestic cattle on forest and woody ecosystems in southern South America. Plant Ecology, 219(8), 913-925. doi: 10.1007/s11258-018-0846-y

McEvoy, PM; Flexen, M; McAdam, JH. 2006. The effects of livestock grazing on ground flora in broadleaf woodlands in Northern Ireland. Forest Ecology and Management, 225, 39-50. doi: 10.1016/j.foreco.2005.12.026

McEvoy, PM; McAdam, JH. 2008. Sheep grazing in young oak Quercus spp. and ash Fraxinus excelsior plantations: vegetation control, seasonality and tree damage. Agroforestry Systems, 74:199211. doi: $10.1007 / \mathrm{s} 10457-008-9121-\mathrm{x}$

McEvoy, PM; McAdam, JH; Mosquera-Losada, M; Rigueiro-Rodriguez, A. 2006. Tree regeneration and sapling damage of pedunculate oak Quercus robur in a grazed forest in Galicia, NW Spain: a comparison of continuous and rotational grazing systems. Agroforestry Systems, 66(2), 85-92. doi: 10.1007/s10457-005-2916-0

Milios, E; Pipinis, E; Kitikidou, K; Batziou, M; Chatzakis, S; Akritidou, S. 2014. Are sprouts the dominant form of regeneration in a lowland Quercus pubescens-Quercus frainetto remnant forest in Northeastern Greece? A regeneration analysis in the context of grazing. New Forests, 45(2), 165-177. doi: 10.1007/s11056-013-9399-z

Mitchell, FJG; Kirby, KJ. 1990. The impact of large herbivores conservation of semi-natural woods British uplands. Forestry, 63(4), 333-353. doi: 10.1093/forestry/63.4.333

Mitchell, JE; Rodgers, RT. 1985. Food-habits and distribution of cattle on a forest and pasture range in Northern Idaho. Journal of Range Management, 38(3), 214-220. doi: 10.2307/3898969

Morgan, RK. 1991. The role of protective understorey in the regeneration system of a heavily browsed woodland. Vegetatio, 92(2), 119-132. doi: 10.1007/BF00036033

Nakashizuka, T; Numata, M. 1982. Regeneration process of climax beech forests II. Structure of a forest under the influences of grazing. Japan Journal of Ecology, 32, 473-482.

Noack, FAW; Manthey, M; Ruitenbeek, JH; Mohadjer, MRM. 2010. Separate or mixed production of timber, livestock and biodiversity in the Caspian Forest. Ecological Economics, 70(1): 67-76. doi: 10.1016/j.ecolecon.2010.07.033

Norbu, L. 2002. Grazing management in broadleaf forests - Bhutan. Journal of Bhutan Studies, 7, 99129

Papachristou, TG; Platis, PD. 2011. The impact of cattle and goats grazing on vegetation in oak stands of varying coppicing age. Acta Oecologica-International Journal of Ecology, 37(1), 16-22. doi: 10.1016/j.actao.2010.11.001

Pearson, HA; Whitaker, LB. 1974. Forage and cattle responses to different grazing intensities on southern pine ridge. Journal of Range Management, 27(6), 444-446. doi: 10.2307/3896718

Peterken, GF; Tubbs, CR. 1965. Woodland regeneration in the New Forest, Hampshire, since 1651. Journal of Applied Ecology, 2(1), 159-170. doi: 10.2307/2401702

Pollock, ML; Milner, JM; Waterhouse, A; Holland, JP; Legg, CJ. 2005. Impacts of livestock in regenerating upland birch woodlands in Scotland. Biological Conservation, 123(4), 443-452. doi: 10.1016/j.biocon.2005.01.006

Popp, A; Scheibe, KM. 2014. The ecological influence of large herbivores behavior - and habitat utilization of cattle and horses. Applied Ecology and Environmental Research, 12(3), 681-693. doi: 10.15666/aeer/1203_68169

Putman, RJ; Pratt, RM; Ekins, JR; Edwards, PJ. 1987. Food and feeding behaviour of cattle and ponies in the New Forest, Hampshire. Journal of Applied Ecology, 24(2), 369-380. doi: $10.2307 / 2403881$

Rhodes, AC; Larsen, RT; Clair, SBS. 2018. Differential effects of cattle, mule deer, and elk herbivory on aspen forest regeneration and recruitment. Forest Ecology and Management, 422, 273-280. doi: 10.1016/j.foreco.2018.04.013 
Rummell, RS. 1951. Some effects of livestock grazing on ponderosa pine forest and range in central Washington. Ecology, 32(4), 594-607. doi: 10.2307/1932728

Samojlik, T; Fedotova, A; Kuijper, DPJ. 2016. Transition from traditional to modern forest management shaped the spatial extent of cattle pasturing in Białowieża Primeval Forest in the nineteenth and twentieth centuries. Ambio, 45(8), 904-918. doi: 10.1007/s13280-016-0795-4

Schulze, ED; Bouriaud, O; Waldchen, J; Eisenhauer, N; Walentowski, H; Seele, C; Heinze, E; Pruschitzki, U; Danila, G; Marin, G; Hessenmoller, D; Bouriaud, L; Teodosiu, M. 2014. Ungulate browsing causes species loss in deciduous forests independent of community dynamics and silvicultural management in Central and Southeastern Europe. Annals of Forest Research, 57(2), 267-288. doi: 10.15287/afr.2014.273

Shakeri, Z; Mohadjer, MRM; Simberloff, D; Etemad, V; Assadi, M; Donath, TW; Otte, A; Eckstein, RL. 2012. Plant community composition and disturbance in Caspian Fagus orientalis forests: which are the main driving factors? Phytocoenologia, 41(4), 247-263. doi: 10.1127/0340269X/2011/0041-0513

Sharrow, SH; Leininger, WC; Osman, KA. 1992. Sheep grazing effects on coastal Douglas fir forest growth: a ten-year perspective. Forest Ecology and Management, 50(1-2), 75-85. doi: 10.1016/0378-1127(92)90315-Z

Sharrow, SH; Leininger, WC; Rhodes, B. 1989. Sheep grazing as a silvicultural tool to suppress brush. Journal of Range Management, 42(1), 2-4. doi: 10.2307/3899647

Smale, MC; Dodd, MB; Burns, BR; Power, IL. 2008. Long-term impacts of grazing on indigenous forest remnants on North Island hill country, New Zealand. New Zealand Journal of Ecology, 32(1): 5766.

Strandberg, B; Kristiansen, SM; Tybirk, K. 2005. Dynamic oak-scrub to forest succession: Effects of management on understorey vegetation, humus forms and soils. Forest Ecology and Management, 211 (3) 318-328. doi: 10.1016/j.foreco.2005.02.051

Tasker, EM; Bradstock, RA. 2006. Influence of cattle grazing practices on forest understorey structure in north-eastern New South Wales. Austral Ecology, 31(4), 490-502. doi: 10.1111/j.14429993.2006.01597.x

Thomason, D. 1995. Grazing in western sessile oakwoods in the Lake District. Biological Journal of the Linnean Society, 56(Suppl.), 49-51. doi: 10.1111/j.1095-8312.1995.tb01119.x

Tubbs, CR. 1997. The ecology of pastoralism in the New Forest. British Wildlife, 9(1), 7-16.

Vanbergen, AJ, Hails, RS, Watt, AD, Jones, TH. 2006. Consequences for host-parasitoid interactions of grazing-dependent habitat heterogeneity. Journal of Animal Ecology, 75(3), 789-801. doi: 10.1111/j.1365-2656.2006.1099.x

Van Uytvanck, J; Hoffmann, M. 2009. Impact of grazing management with large herbivores on forest ground flora and bramble understorey. Acta Oecologica-International Journal of Ecology, 35(4), 523-532. doi: 10.1016/j.actao.2009.04.001

Walker, SC; Anderson, VJ; Fugal, RA. 2015. Big game and cattle influence on aspen community regeneration following prescribed fire. Rangeland Ecology and Management, 68(4), 354-358. doi: 10.1016/j.rama.2015.05.005

Zhang, HM; Wang, Y; Zhang, ZB. 2009. Domestic goat grazing disturbance enhances tree seed removal and caching by small rodents in a warm-temperate deciduous forest in China. Wildlife Research, 36(7), 610-616. doi: 10.1071/WR09001 


\section{Supporting information 2}

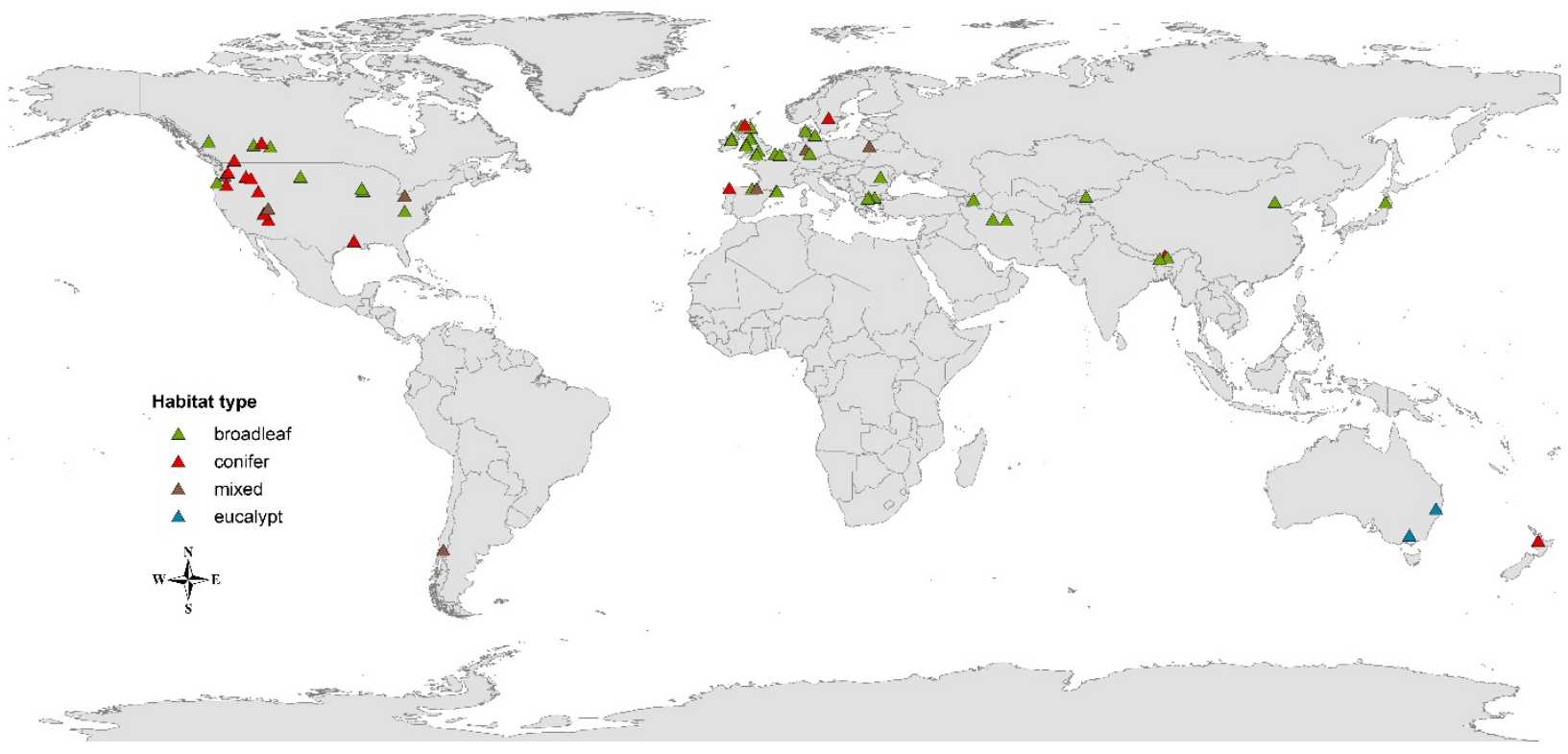

Fig. S1. Location of the studies considered in the review and the major forest types where these studies have been conducted (basemap source: ArcGIS.10.1.ESRI/ArcGIS_online world countries) 


\section{Supporting information 3}

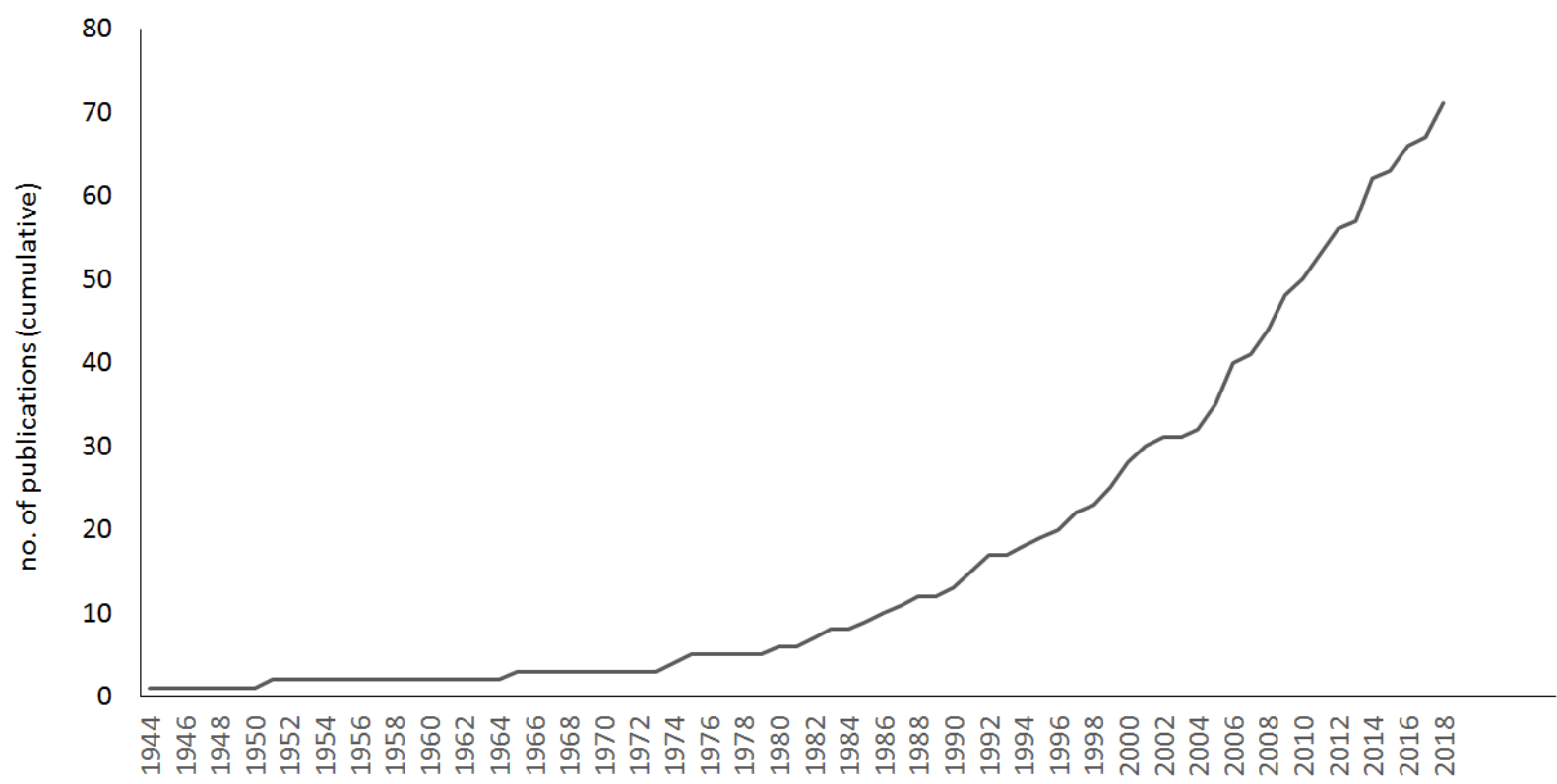

year of publication

Fig. S2. The cumulative number of the 71 publications included in the review, addressing the issue of domestic livestock grazing in temperate forests 


\section{Supporting information 4}

Table S1. Impacts of livestock grazing on forest elements. 'Change' marks situations when the direction of the trend was unclear

\begin{tabular}{|c|c|}
\hline Impacts of livestock grazing on forest elements & References \\
\hline \multicolumn{2}{|l|}{$\begin{array}{l}\text { Canopy biomass } \\
\text { (stand volume, density) }\end{array}$} \\
\hline Decrease & $\begin{array}{l}\text { Mitchell \& Kirby, 1990; Vanbergen et al., } 2006 \\
\text { Buffum et al., 2009; Noack et al., 2010; Lindgren } 8 \\
\text { Sullivan, 2012; Milios et al., } 2014\end{array}$ \\
\hline Neutral - no effect & $\begin{array}{l}\text { Cutter et al., 1998; Lindgren \& Sullivan, } 2012 \\
\text { Galleguillos et al., } 2018\end{array}$ \\
\hline Increase & $\begin{array}{l}\text { Madany \& West, 1983; Steven et al., 1992; Belsky } 8 \\
\text { Blumenthal, 1997; Bromham et al., 1999; Borman } \\
\text { 2004; Ford et al., } 2018\end{array}$ \\
\hline \multicolumn{2}{|l|}{ Change } \\
\hline \multicolumn{2}{|l|}{ Canopy species composition/richness } \\
\hline \multicolumn{2}{|l|}{ Decrease } \\
\hline Neutral - no effect & Garin et al., 2000 \\
\hline Increase & Ford et al., 2018 \\
\hline Change & Madany \& West, 1983; Belsky \& Blumenthal, 1997 \\
\hline \multicolumn{2}{|l|}{ Shrub biomass } \\
\hline Decrease & $\begin{array}{l}\text { Tubbs, 1977; Nakashizuka \& Numata, 1982; Mitchel } \\
\text { \& Kirby, 1990; Sharrow et al., 1992; Kirby et al., } 1994 \\
\text { Bromham et al., 1999; Borman, 2004; Lamoot et al. } \\
\text { 2005; Chauchard et al., 2006; Darabant et al., } 2007 \\
\text { Cooper \& McCann, 2011; Lindgren \& Sullivan, } 2012 \\
\text { Mayerfeld et al., } 2016\end{array}$ \\
\hline Neutral - no effect & Lamoot et al., 2005 \\
\hline Increase & $\begin{array}{l}\text { Linhart \& Whelan, 1980; Emborg et al., } 2000 \\
\text { Konstantinidis et al., 2008; Noack et al., } 2010 \\
\text { Samojlik et al., 2016; Galleguillos et al., } 2018\end{array}$ \\
\hline \multicolumn{2}{|r|}{ ( } \\
\hline \multicolumn{2}{|l|}{ Shrub species composition/richness } \\
\hline Decrease & Lindgren \& Sullivan, 2012 \\
\hline \multicolumn{2}{|l|}{ Neutral - no effect } \\
\hline Increase & $\begin{array}{l}\text { Linhart \& Whelan, 1980; Emborg et al., } 2000 \\
\text { Samojlik et al., } 2016\end{array}$ \\
\hline Change & $\begin{array}{l}\text { Adams, 1975; Fitzgerald et al., 1986; Kirby et al. } \\
\text { 1994; Garin et al., 2000; Konstantinidis et al., } 2008 \\
\text { Smale et al., 2008; Noack et al., 2010; Papachristou } \\
\text { \& Platis, 2011; Shakeri et al., } 2012\end{array}$ \\
\hline
\end{tabular}




\section{Herb biomass \\ Decrease}

Linhart \& Whelan, 1980; Fitzgerald et al., 1986; Sharrow et al., 1989; Sharrow et al., 1992; Kirby et al., 1994; Thomason 1995; Belsky \& Blumenthal 1997; Tubbs 1997; Latham \& Blackstock 1998; Bromham et al. 1999; Garin et al. 2000; Humphrey \& Patterson 2000; Fraser et al. 2001; Borman 2004; McEvoy et al. 2006a; Van Uytvanck \& Hoffmann 2009; Zhang et al. 2009; Papachristou \& Platis 2011; Lindgren \& Sullivan 2012; Shakeri et al. 2012

\begin{tabular}{ll}
\hline Neutral - no effect & \\
\hline Increase & Vanbergen et al. 2006; Galleguillos et al. 2018 \\
\hline Change & \\
\hline Herb species composition/richness & Smale et al. 2008 \\
\hline Decrease & Beymer \& Klopatek, 1992; Epple 2001; Fortuny et al. \\
& 2014; Ford et al. 2018 \\
\hline Neutral - no effect & Madany \& West 1983; Kirby et al. 1994; Bromham et \\
& al. 1999; Humphrey \& Patterson 2000; McEvoy et al. \\
& 2006a; Tasker \& Bradstock 2006; Vanbergen et al. \\
& 2006; Lesica 2009; Cooper \& McCann 2011; Shakeri et \\
& al. 2012; Galleguillos et al. 2018 \\
\hline Change & Pearson \& Whitaker 1974; Kirby et al. 1994; Latham \\
& \& Blackstock 1998; Noack et al. 2010; Kaufmann et \\
& al. 2013 \\
\hline Regeneration biomass & Peterken \& Tubbs 1965; Adams 1975; Linhart \& \\
\hline Decrease & Whelan 1980; Fitzgerald et al. 1986; Kirby et al. \\
& 1994; Hester et al. 1996; Latham \& Blackstock 1998; \\
& Garin et al. 2000; Fraser et al. 2001; Chauchard et al. \\
& 2006; McEvoy et al. 2006b; Buffum et al. 2009; \\
& Papachristou \& Platis 2011; Kaufmann et al. 2014; \\
& Milios et al. 2014; Schulze et al. 2014; Kardell 2016; \\
& Mayerfeld et al. 2016; Samojlik et al. 2016; Ford et \\
al. 2018; Mazzini et al. 2018; Rhodes et al. 2018 \\
\hline Rummel 1951; Kingery \& Graham 1991; Cutter et al. \\
1998; Pollock et al. 2005; Darabant et al. 2007; \\
Buffum et al. 2009 \\
\hline Nakashizuka \& Numata 1982; Madany \& West 1983; \\
Sharrow et al. 1989; Mitchell \& Kirby 1990; Sharrow \\
et al. 1992; Belsky \& Blumenthal 1997; Darabant et \\
al. 2007; Zhang et al. 2009 \\
\hline
\end{tabular}




\begin{tabular}{|c|c|}
\hline Change & $\begin{array}{l}\text { Morgan 1991; Thomason 1995; McEvoy \& McAdam } \\
\text { 2008; Lesica 2009; Shakeri et al. 2012; Laskurain et } \\
\text { al. } 2013\end{array}$ \\
\hline \multicolumn{2}{|c|}{ Regeneration species composition/richness } \\
\hline Decrease & Latham \& Blackstock 1998; Ford et al. 2018 \\
\hline \multicolumn{2}{|l|}{ Neutral - no effect } \\
\hline \multicolumn{2}{|l|}{ Increase } \\
\hline Change & $\begin{array}{l}\text { Linhart \& Whelan 1980; Fitzgerald et al. 1986; } \\
\text { Morgan 1991; Hester et al. 1996; Garin et al. 2000; } \\
\text { Fraser et al. 2001; Zhang et al. 2009; Shakeri et al. } \\
\text { 2012; Laskurain et al. 2013; Kaufmann et al. } 2014\end{array}$ \\
\hline \multicolumn{2}{|l|}{ Bryophytes biomass } \\
\hline Decrease & $\begin{array}{l}\text { Latham \& Blackstock 1998; Strandberg et al. 2005; } \\
\text { Vanbergen et al. 2006; Darabant et al. 2007; Smale } \\
\text { et al. 2008; Laskurain et al. } 2013\end{array}$ \\
\hline Neutral - no effect & McEvoy et al. 2006a \\
\hline Increase & Mitchell \& Kirby 1990; Kirby et al. 1994 \\
\hline Change & Thomason 1995 \\
\hline \multicolumn{2}{|c|}{ Bryophytes species composition/richness } \\
\hline \multicolumn{2}{|l|}{ Decrease } \\
\hline Neutral - no effect & Beymer \& Klopatek 1992 \\
\hline Increase & Kirby et al. 1994; Humphrey \& Patterson 2000 \\
\hline Change & Thomason 1995 \\
\hline \multicolumn{2}{|c|}{ Overall species composition/richness } \\
\hline Decrease & $\begin{array}{l}\text { Dambach 1944; Norbu 2002; McEvoy et al. 2006a; } \\
\text { Smale et al. 2008; Lindgren \& Sullivan 2012; Ford et } \\
\text { al. } 2018\end{array}$ \\
\hline Neutral - no effect & Walker et al. 2015; Galleguillos et al. 2018 \\
\hline Increase & $\begin{array}{l}\text { Beymer \& Klopatek 1992; Strandberg et al. 2005; } \\
\text { McEvoy et al. 2006a; Vanbergen et al. 2006; Noack } \\
\text { et al. 2010; Cooper \& McCann 2011; Fortuny et al. } \\
\text { 2017; Galleguillos et al. } 2018\end{array}$ \\
\hline \multicolumn{2}{|l|}{ Change } \\
\hline \multicolumn{2}{|l|}{ Invasive species biomass } \\
\hline Decrease & $\begin{array}{l}\text { Chauchard et al. 2006; Mayerfeld et al. 2016; } \\
\text { Mazzini et al, } 2018\end{array}$ \\
\hline \multicolumn{2}{|l|}{ Neutral - no effect } \\
\hline Increase & Smale et al. 2008; Galleguillos et al. 2018 \\
\hline \multicolumn{2}{|l|}{ Change } \\
\hline \multicolumn{2}{|l|}{ Habitat heterogeneity } \\
\hline \multicolumn{2}{|l|}{ Decrease } \\
\hline Neutral - no effect & \\
\hline
\end{tabular}




\begin{tabular}{|c|c|}
\hline Increase & $\begin{array}{l}\text { Madany \& West, 1983; Mitchell \& Kirby, 1990; Kirby } \\
\text { et al., 1994; Hester et al., 1996; Tubbs, 1997; } \\
\text { McEvoy et al., 2006a; Vanbergen et al., 2006; Van } \\
\text { Uytvanck \& Hoffmann, 2009; Zhang et al., } \\
\text { 2009Lindgren \& Sullivan, 2012; Laskurain et al., } \\
\text { 2013; Fortuny et al., } 2014\end{array}$ \\
\hline \multicolumn{2}{|l|}{ Change } \\
\hline \multicolumn{2}{|l|}{ Litter cover } \\
\hline Decrease & $\begin{array}{l}\text { Dambach 1944; Adams 1975; Linhart \& Whelan } \\
\text { 1980; Mitchell \& Kirby 1990; Belsky \& Blumenthal } \\
\text { 1997; Latham \& Blackstock 1998; Bromham et al. } \\
\text { 1999; Humphrey \& Patterson 2000; Epple 2001; } \\
\text { Strandberg et al. 2005; McEvoy et al. 2006a; } \\
\text { Vanbergen et al. 2006; Smale et al. 2008; Shakeri et } \\
\text { al. 2012; Laskurain et al. 2013; Galleguillos et al. } \\
2018\end{array}$ \\
\hline Neutral - no effect & Beymer \& Klopatek 1992 \\
\hline \multicolumn{2}{|l|}{ Increase } \\
\hline Change & Darabant et al. 2007 \\
\hline \multicolumn{2}{|l|}{ Bare soil surface } \\
\hline \multicolumn{2}{|l|}{ Decrease } \\
\hline Neutral - no effect & Humphrey \& Patterson 2000 \\
\hline Increase & $\begin{array}{l}\text { Mitchell \& Kirby 1990; Beymer \& Klopatek 1992; } \\
\text { Kirby et al. 1994; Belsky \& Blumenthal 1997; Latham } \\
\text { \& Blackstock 1998; Bromham et al. 1999; McEvoy et } \\
\text { al. 2006a; Vanbergen et al. 2006; Smale et al. 2008; } \\
\text { Zhang et al. 2009; Shakeri et al. 2012; Laskurain et al. } \\
\text { 2013; Galleguillos et al. } 2018\end{array}$ \\
\hline \multicolumn{2}{|r|}{ 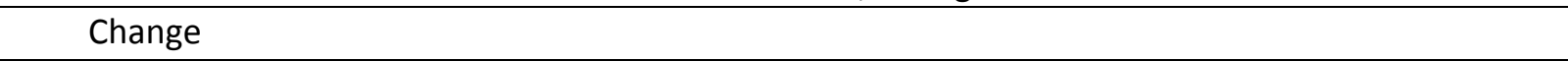 } \\
\hline \multicolumn{2}{|l|}{ Deadwood volume } \\
\hline Decrease & $\begin{array}{l}\text { Latham \& Blackstock 1998; McEvoy et al. 2006a; } \\
\text { Smale et al. } 2008\end{array}$ \\
\hline \multicolumn{2}{|l|}{ Neutral - no effect } \\
\hline \multicolumn{2}{|l|}{ Increase } \\
\hline Change & \\
\hline
\end{tabular}




\section{Supporting information 5}

Table S2. The main biotic and abiotic factors that influence the effects of livestock grazing in forests

\begin{tabular}{|c|c|}
\hline Effects depend on & Example quotations \\
\hline \multirow[t]{2}{*}{$\begin{array}{l}\text { Palatability of plant species } \\
\text { and availability of forage } \\
\text { alternatives (development } \\
\text { stage of species influences } \\
\text { forage preference) }\end{array}$} & $\begin{array}{l}\text { Rose and raspberry were highly } \\
\text { preferred as young shoots in the } \\
\text { first year. Raspberry continued to } \\
\text { be favoured in the second year as } \\
\text { it produced new tender shoots } \\
\text { from underground rhizomes. } \\
\text { (Fitzgerald et al., 1986) }\end{array}$ \\
\hline & $\begin{array}{l}\text { The combination of decreased } \\
\text { meadow and aspen understory } \\
\text { vegetation quantity and } \\
\text { nutritional quality lead to } \\
\text { increased utilization on aspen } \\
\text { suckers, particularly mid- to late- } \\
\text { growing season. } \\
\text { (Jones et al., 2011) }\end{array}$ \\
\hline
\end{tabular}

Grazer species, breed type, livestock age and level of forest adaptation (cattle may cause damage also by trampling and rubbing, while sheep mostly by grazing)
Sheep breeds with strong herding instincts (Rambouillet, Corriedale) are easier to control on forest sites. With good shepherding, breeds which graze in more dispersed patterns, such as Suffolk, can be used effectively. The emphasis should be on the quality of shepherding effort, rather than simply on the breed. Mature dry ewes are the most suitable animals for a grazing flock. (Fraser et al., 2001)

Grazing regime, stocking density and distribution (vegetation can benefit from under- and overgrazing as well)

\section{Damage to regenerating stems in} 2008 was also greater under high intensity (9.3\%) than low intensity (5.0\%) cattle grazing, with high cattle stocking rates leading to 4.3\% [...] more total damage and $3.6 \%$ [...] more browsed saplings. (Kaufmann et al., 2014).

Frequent mob stocking events of $24 \mathrm{~h}$ or thereabouts may provide the desired results whilst potentially reducing damage incurred to saplings.

(McEvoy \& McAdam, 2008)

\section{References}

Adams, 1975; Belsky \& Blumenthal, 1997; Fitzgerald et al., 1986; Fraser et al., 2001; Garin et al., 2000; Jones et al., 2011; Konstantinidis et al., 2008; Shakeri et al., 2012; Smale et al., 2008

Pearson \& Whitaker, 1974; Adams, 1975; Putman et al., 1987; Mitchell \& Kirby, 1990; Tubbs, 1997; Fraser et al., 2001; Lamoot et al., 2005; Walker et al., 2005; Papachristou \& Platis, 2011; Shakeri et al., 2012; Popp \& Sheibe, 2014; Rhodes et al., 2018

Rummel, 1951; Peterken \& Tubbs, 1965; Pearson \& Whitaker, 1974; Adams, 1975; Linhart \& Whelan, 1980; Mitchell \& Kirby, 1990; Kirby et al., 1994; Thomason, 1995; Hester et al., 1996; Belsky \& Blumenthal, 1997; McEvoy et al., 2006b; McEvoy \& McAdam, 2008; Buffum et al., 2009; Laskurain et al., 2013; Kaufmann et al., 2014; Milios et al., 2014; Samojlik et al., 2016; Galleguillos et al., 2018; Rhodes et al., 2018 


\begin{tabular}{|c|c|c|}
\hline $\begin{array}{l}\text { Forest characteristics } \\
\text { (e.g. habitat type, stand } \\
\text { structure and age, forestry } \\
\text { treatments, canopy closure } \\
\text { - cattle avoid clear-cuts) }\end{array}$ & $\begin{array}{l}\text { The influence of cattle grazing on } \\
\text { plant community abundance and } \\
\text { diversity may be directly affected } \\
\text { by forest enhancement treatments } \\
\text { of repeated fertilization. } \\
\text { (Lindgren \& Sullivan, 2012). } \\
\text { Uncut forests were preferred by } \\
\text { cattle [...] partially harvested areas } \\
\text { and burned brush piles were } \\
\text { neither preferred nor avoided. } \\
\text { (Kaufmann et al., 2013) }\end{array}$ & $\begin{array}{l}\text { Adams, 1975; Belsky \& } \\
\text { Blumenthal, 1997; Garin et al., } \\
\text { 2000; Pollock et al., 2005; } \\
\text { Papachristou \& Platis, 2011; } \\
\text { Lindgren \& Sullivan, 2012; } \\
\text { Shakeri et al., 2012; Kaufmann } \\
\text { et al., 2013; Popp \& Sheibe, } \\
2014\end{array}$ \\
\hline $\begin{array}{l}\text { Timing of grazing } \\
\text { (winter grazing may favour } \\
\text { regeneration, while late } \\
\text { summer grazing may favour } \\
\text { vernal species) }\end{array}$ & $\begin{array}{l}\text { Preference for aspen at } \\
\text { commencement of grazing was } \\
\text { lower early in the season than late. } \\
\text { As early grazing proceeded and } \\
\text { alternative species were removed, } \\
\text { aspen became more acceptable. } \\
\text { (Fitzgerald et al., 1986) } \\
\text { A grazing regime following the end } \\
\text { of the growing season appears to } \\
\text { have little effect on tree growth, } \\
\text { despite more damage occurring to } \\
\text { trees at this time. } \\
\text { (McEvoy and McAdam 2008) }\end{array}$ & $\begin{array}{l}\text { Fitzgerald et al., 1986; Putman } \\
\text { et al., 1987; Sharrow et al., } \\
\text { 1992; Hester et al., 1996; } \\
\text { Belsky \& Blumenthal, 1997; } \\
\text { Garin et al., 2000; Fraser et al., } \\
\text { 2001; Lamoot et al., 2005; } \\
\text { McEvoy et al., 2006a; McEvoy } \\
\& \quad \text { McAdam, 2008; Van } \\
\text { Uytvanck \& Hoffmann, 2009; } \\
\text { Jones et al., 2011; Kaufmann } \\
\text { et al., } 2014\end{array}$ \\
\hline $\begin{array}{l}\text { External factors (e.g. fire, } \\
\text { precipitation, slope, herder, } \\
\text { distance from herd camp } \\
\text { and water availability } \\
\text { influence the intensity of } \\
\text { grazing) }\end{array}$ & $\begin{array}{l}\text { The function has a maximum at a } \\
\text { distance of about } 100 \mathrm{~m} \text { from } \\
\text { herdsmen camps [...]. Thus, plant } \\
\text { diversity can also be expressed as } \\
\text { a function of the distance to } \\
\text { herdsmen camps. } \\
\text { (Noack et al., 2010) } \\
\text { Annual variation in precipitation } \\
\text { and biomass production must be } \\
\text { accounted for in grazing } \\
\text { strategies, with attention paid to } \\
\text { low herbaceous vegetation } \\
\text { production years. } \\
\text { (Jones et al., 2011) }\end{array}$ & $\begin{array}{l}\text { Dambach, 1944; Pearson \& } \\
\text { Whitaker, 1974; Adams, 1975; } \\
\text { Madany \& West, 1983; } \\
\text { Thomason, 1995; Belsky \& } \\
\text { Blumenthal, 1997; Tasker \& } \\
\text { Bradstock, 2006; Van } \\
\text { Uytvanck \& Hoffmann, 2009; } \\
\text { Noack et al., 2010; Jones et al., } \\
\text { 2011; Kaufmann et al., 2013; } \\
\text { Fortuny et al., 2014; Walker et } \\
\text { al., 2015; Rhodes et al., } 2018\end{array}$ \\
\hline
\end{tabular}




\section{Supporting information 6}

Table S3. Practical recommendations for management of livestock grazing in temperate forests

\begin{tabular}{llll}
\hline Overall recommendation & Management & Habitat type \\
\hline Major habitat types & recommendations & Reference \\
\hline Benefits (B) / Disadvantages (D) & (country)
\end{tabular}$\quad$

1. Some kind of management

Broadleaf, Europe

B: Considerable potential in vegetation management

D: -

Reduction, but not

complete exclusion

Ancient

seminatural

woodland

Kirby et al.,

(UK)

B: Reduces the patch sizes of monospecific stands (Rubus, Pteridium) and encourages an increase in botanical diversity

D: -

Light grazing in late summer

Broadleaf
woodlands (oak,
ash, beech)
(Ireland)

B: Eliminates bramble thus

favouring rare species

D: Reduce or prevent regeneration because seedlings are killed by grazing and the soil is compacted

B: Control the growth of grasses, bilberry and bramble, to allow some regeneration of trees and shrubs in canopy gaps

D: Seedlings are eaten, if the stocking rate is too high
Controlled, light grazing by sheep in winter and early spring
Oak dominated woodland

(UK)
Linhart \&

Whelan, 1980
Flexibility of stocking and grazing periods, dictated by grass growth, tree regeneration and weather conditions
Oak woodland (UK) Thomason, 1995
Consider herbage production. The involvement and support of farmers and land owners is essential
Upland seminatural woods (UK)

Mitchell \&

Kirby, 1990

D: May be limiting natural woodland regeneration

Reference to site characteristics is crucial. Importance of controlled experiments
Upland birch (Betula) woodlands (UK)
Pollock et al., 2005 happen

\footnotetext{
B: Higher proportion of the seedlings are reaching sapling height in winter-grazed plots
}

Winter grazing is less detrimental than summer grazing

$\begin{array}{ll}\begin{array}{l}\text { Betula } \\ \text { pubescens, }\end{array} & \text { Hester et al., } \\ \begin{array}{l}\text { Quercus petraea } \\ \text { and Corylus }\end{array} & 1996\end{array}$




\begin{tabular}{|c|c|c|c|}
\hline $\begin{array}{l}\text { D: Saplings will have the potential } \\
\text { to attain canopy height only at the } \\
\text { lowest grazing intensities }\end{array}$ & & $\begin{array}{l}\text { avellana with } \\
\text { Sorbus aucuparia } \\
\text { and Fraxinus } \\
\text { excelsior } \\
\text { (UK) }\end{array}$ & \\
\hline $\begin{array}{l}\text { B: Reducing competitive grasses in } \\
\text { plantations without causing } \\
\text { significant damage to the trees } \\
\text { D: Damage to the lateral branches } \\
\text { of oak and ash. Smaller annual } \\
\text { increase in oak canopy diameter }\end{array}$ & $\begin{array}{l}\text { A grazing regime } \\
\text { following the end of the } \\
\text { growing season appears } \\
\text { to have little effect on } \\
\text { tree growth, despite } \\
\text { more damage occurring } \\
\text { to trees at this time. } \\
\text { Frequent mob-stocking is } \\
\text { recommended over } \\
\text { longer grazing periods; } \\
\text { thus, livestock should be } \\
\text { removed from the } \\
\text { plantation before quality } \\
\text { forage becomes limited }\end{array}$ & $\begin{array}{l}\text { Quercus and } \\
\text { Fraxinus excelsior } \\
\text { plantation } \\
\text { established on } \\
\text { former } \\
\text { pastureland } \\
\text { (UK) }\end{array}$ & $\begin{array}{l}\text { McEvoy \& } \\
\text { McAdam, } 2008\end{array}$ \\
\hline $\begin{array}{l}\text { B: Decrease cover of Rubus } \\
\text { D: - }\end{array}$ & $\begin{array}{l}\text { Moderate, rotational } \\
\text { grazing. Providing } \\
\text { temporal time gaps in } \\
\text { grazing may prevent } \\
\text { excessive grazing and } \\
\text { trampling damage. Best } \\
\text { forage quality for Rubus is } \\
\text { reached in late spring }\end{array}$ & $\begin{array}{l}\text { Alno-Padion, } \\
\text { Carpinion forest } \\
\text { (Belgium) }\end{array}$ & $\begin{array}{l}\text { Van Uytvanck \& } \\
\text { Hoffmann, } 2009\end{array}$ \\
\hline $\begin{array}{l}\text { B: Good as a nature conservation } \\
\text { management } \\
\text { D: - }\end{array}$ & $\begin{array}{l}\text { Combination of cattle and } \\
\text { ponies }\end{array}$ & $\begin{array}{l}\text { Populus tremula, } \\
\text { P. canadensis, } \\
\text { P. canescens, } \\
\text { Ulmus minor and } \\
\text { Alnus glutinosa } \\
\text { forest } \\
\text { (Belgium) }\end{array}$ & $\begin{array}{l}\text { Lamoot et al., } \\
2005\end{array}$ \\
\hline $\begin{array}{l}\text { B: Cattle greatly reduce the } \\
\text { regeneration of non-native black } \\
\text { pine } \\
\text { D: - }\end{array}$ & $\begin{array}{l}\text { Lower ungulate densities } \\
\text { are sufficient to eliminate } \\
\text { almost all tree } \\
\text { regeneration }\end{array}$ & $\begin{array}{l}\text { Mixed beech- } \\
\text { oak-maple } \\
\text { forest with non- } \\
\text { native black } \\
\text { pine } \\
\text { (France) }\end{array}$ & $\begin{array}{l}\text { Chauchard et al., } \\
2006\end{array}$ \\
\hline
\end{tabular}




\begin{tabular}{|c|c|c|c|}
\hline $\begin{array}{l}\text { B: Control oak shoots in degraded } \\
\text { oak forests to be converted into } \\
\text { conifer forests } \\
\text { D: - }\end{array}$ & $\begin{array}{l}\text { Consider the type, breed, } \\
\text { and class of livestock. } \\
\text { Forest trees should have } \\
\text { heights beyond the reach }\end{array}$ & $\begin{array}{l}\text { Oak woodland } \\
\text { converted to } \\
\text { conifer forest } \\
\text { (Greece) }\end{array}$ & $\begin{array}{l}\text { Papachristou \& } \\
\text { Platis, 2011; } \\
\text { Samojlik et al., } \\
2016\end{array}$ \\
\hline
\end{tabular}

\begin{tabular}{ll}
\hline Broadleaf, mixed and conifer in N. Am \\
\hline $\begin{array}{ll}\text { B: Compatibility of cattle grazing } \\
\text { and sustainable forest }\end{array}$ \\
$\begin{array}{ll}\text { management } & \text { No grazing should occur } \\
\text { D: - } & \text { in May-June. Grazing } \\
& \text { should be allowed only } \\
& \text { when saplings are above } \\
& 1.5 \mathrm{~m} \text { height }\end{array}$
\end{tabular}

Young Populus

tremuloides,

P. balsamifera

and Betula

papyrifera

forest with

Kaufmann et al.,

secondary Picea

glauca

(Canada, Alberta)

The effects of cattle grazing on plants cannot be generalized as beneficial or detrimental, as the response is undoubtedly a function of grazing intensity and nutrient status of the ecosystem

Lodgepole pine,

Strategies for conservation douglas fir. Picea of plant diversity should engelmannii $\times P$. include a diversity of forest glauca and Abies enhancement treatments, lasiocarpa including grazing

(Canada, British

Columbia)

Pinus contorta

B: Sheep grazing for vegetation control, a cost-effective tool

D: Potential for crop tree damage

Optimum flock size and appropriate timing importance of herding and Picea glauca

$\mathrm{x}$ sitchensis

(Canada, British

Columbia and

Alberta)
Lindgren \&

Sullivan, 2012
Mixed conifer
(Pinus, Abies)
forest with Jones et al.,
aspen, Populus 2011
tremuloides
(USA, California)

Fraser et al., 2001
B: More area for feeding the animals, shade and shelter from heat and wind, suppression of no- xious species such as Rosa multi- flora. Reduced shrub cover for improved recreation. Natural distri- bution of manure, animal exercise. Keeping property taxes lower
D: Damage to seedlings and saplings of desirable timber species. Less growth of herbaceous plants. Higher densities of undesirable species. Extra effort to maintain fences and difficulties in dividing the woodlots
Separating the top of the hills and valleys, as cattle prefer to graze on less steep slopes. Rotating into the most shaded paddocks at the hottest times. Actively managing canopy conditions to promote adequate light penetration for forages. Build exclosures around young trees
Prunus serotina, Acer negundo, Ulmus rubra, Quercus alba, Galleguillos et Fraxinus al., 2018 americana (USA, Wisconsin)


into paddocks for rotational grazing,

and erosion along cattle trails

\begin{tabular}{|c|c|c|c|}
\hline $\begin{array}{l}\text { B: Higher income from the same } \\
\text { area, if it used also as a grazing area } \\
\text { D: Damage to seedlings }\end{array}$ & $\begin{array}{l}\text { Restricting grazing during } \\
\text { the first months after } \\
\text { planting }\end{array}$ & $\begin{array}{l}\text { Pinus ponderosa } \\
\text { plantation } \\
\text { (USA, Idaho) }\end{array}$ & $\begin{array}{l}\text { Kingery \& } \\
\text { Graham, } 1991\end{array}$ \\
\hline $\begin{array}{l}\text { B: - } \\
\text { D: Combined big game and } \\
\text { livestock severely reduces } \\
\text { regeneration }\end{array}$ & $\begin{array}{l}\text { Careful consideration of } \\
\text { limiting, but not } \\
\text { necessarily eliminating, } \\
\text { large ungulate utilization }\end{array}$ & $\begin{array}{l}\text { Mixed aspen- } \\
\text { conifer forest } \\
\text { (USA, Utah) }\end{array}$ & $\begin{array}{l}\text { Walker et al., } \\
2015\end{array}$ \\
\hline $\begin{array}{l}\text { B: - } \\
\text { D: Ungulate population size of any } \\
\text { species or combination of species } \\
\text { at sufficient density can cause } \\
\text { aspen regeneration failure }\end{array}$ & $\begin{array}{l}\text { Cattle, mule deer, and elk } \\
\text { differ in their preference } \\
\text { for aspen. Aspen at lower } \\
\text { elevation are more } \\
\text { susceptible to ungulate } \\
\text { herbivory. Identify } \\
\text { important thresholds for } \\
\text { aspen recruitment }\end{array}$ & $\begin{array}{l}\text { Mixed aspen- } \\
\text { conifer forest } \\
\text { Populus } \\
\text { tremuloides, } \\
\text { Abies lasiocarpa, } \\
\text { Abiesconcolor } \\
\text { (USA, Utah) }\end{array}$ & $\begin{array}{l}\text { Rhodes et al., } \\
2018\end{array}$ \\
\hline $\begin{array}{l}\text { No differences between grazed and } \\
\text { non-grazed woods in long term as } \\
\text { regards growth rate or total ring } \\
\text { width }\end{array}$ & $\begin{array}{l}\text { Continuing the } 30 \text { years } \\
\text { practice of regulating } \\
\text { number per acre in } \\
\text { accordance with the } \\
\text { forage production }\end{array}$ & $\begin{array}{l}\text { Young Pinus } \\
\text { elliottii var. } \\
\text { elliottii plantation } \\
\text { (USA, Lousiana) }\end{array}$ & $\begin{array}{l}\text { Cutter et al., } \\
1998\end{array}$ \\
\hline
\end{tabular}

\section{Broadleaf and conifer in Asia}

B: Income for local communities

D: Unregulated grazing results in reduction of density and change in species composition of broadleaf forest stands
Integrating grazing

function as part of forest management practices
Broadleaf forest managed for industrial timber Norbu, 2002 production (Bhutan)

\begin{tabular}{llll}
\hline $\begin{array}{l}\text { B: Beneficial effects of competition } \\
\text { control }\end{array}$ & $\begin{array}{l}\text { To be controlled to } \\
\text { promote regeneration } \\
\text { after logging in conifer } \\
\text { forests }\end{array}$ & $\begin{array}{l}\text { Mixed conifer } \\
\text { forest } \\
\text { (Bhutan) }\end{array}$ & $\begin{array}{l}\text { Darabant et al., } \\
2007\end{array}$ \\
\hline $\begin{array}{l}\text { B: Grazing is good for the Fagus } \\
\text { seedlings and decreases bamboo } \\
\text { competition }\end{array}$ & $\begin{array}{l}\text { Control against } \\
\text { overgrazing }\end{array}$ & $\begin{array}{l}\text { Beech forest } \\
\text { (Japan) }\end{array}$ & Nakashizuka \& \\
$\begin{array}{l}\text { D: Grazing is necessary, but } \\
\text { overgrazing could be dangerous }\end{array}$ & & Numata, 1982
\end{tabular}




\begin{tabular}{|c|c|c|c|}
\hline \multicolumn{4}{|l|}{ 2. Complete exclusion } \\
\hline $\begin{array}{l}\text { B: Severely grazed woodland can } \\
\text { become rejuvenated within a } \\
\text { reasonably short time after } \\
\text { protection is provided }\end{array}$ & $\begin{array}{l}\text { Encouraging farmers to } \\
\text { exclude livestock from } \\
\text { their woodlots }\end{array}$ & $\begin{array}{l}\text { Beech-sugar } \\
\text { maple woodland } \\
\text { (USA, Ohio) }\end{array}$ & Dambach, 1944 \\
\hline \multicolumn{4}{|l|}{ D: - } \\
\hline $\begin{array}{l}\text { B:- } \\
\text { D: Intense grazing keeps the } \\
\text { regeneration plants in low height }\end{array}$ & $\begin{array}{l}\text { Grazing must be excluded } \\
\text { from the area }\end{array}$ & $\begin{array}{l}\text { Lowland forest } \\
\text { Q. pubescens- } \\
\text { Q. frainetto } \\
\text { (Greece) }\end{array}$ & $\begin{array}{l}\text { Milios et al., } \\
2014\end{array}$ \\
\hline $\begin{array}{l}\text { B: - } \\
\text { D: Introduced pasture grasses were } \\
\text { generally the sole component of } \\
\text { the ground vegetation of grazed } \\
\text { woodland }\end{array}$ & $\begin{array}{l}\text { Limiting disturbance, } \\
\text { assisting owners to fence } \\
\text { woodland remnants, } \\
\text { could benefit } \\
\text { conservation in } \\
\text { fragmented landscapes }\end{array}$ & $\begin{array}{l}\text { Eucalyptus } \\
\text { remnant } \\
\text { woodlands } \\
\text { (Australia) }\end{array}$ & $\begin{array}{l}\text { Bromham et al., } \\
1999\end{array}$ \\
\hline $\begin{array}{l}\text { B: Good for the economy, but } \\
\text { nothing more } \\
\text { D: From a nature conservation } \\
\text { perspective grazing is a harmful } \\
\text { land-use type in this region }\end{array}$ & $\begin{array}{l}\text { Grazing was not part of } \\
\text { the traditional } \\
\text { management and it is not } \\
\text { beneficial for the studied } \\
\text { forest sites }\end{array}$ & $\begin{array}{l}\text { Conifer forest } \\
\text { (New Zealand) }\end{array}$ & $\begin{array}{l}\text { Smale et al., } \\
2008\end{array}$ \\
\hline
\end{tabular}

\begin{tabular}{|c|c|c|c|}
\hline \multicolumn{4}{|c|}{ 3. Arguments against complete exclusion } \\
\hline $\begin{array}{l}\text { D: Exclusion produces dramatic } \\
\text { changes in the structure and } \\
\text { composition of the woods }\end{array}$ & $\begin{array}{l}\text { Need for specific } \\
\text { conservation objectives } \\
\text { and long-term plans. } \\
\text { Control the land next to } \\
\text { the wood as well }\end{array}$ & $\begin{array}{l}\text { Ancient } \\
\text { seminatural } \\
\text { woodland } \\
\text { (UK) }\end{array}$ & $\begin{array}{l}\text { Kirby et al., } \\
1994\end{array}$ \\
\hline $\begin{array}{l}\text { B: Initially beneficial to the eco- } \\
\text { logical condition of the woodland } \\
\text { sites, allowing graze-sensitive, } \\
\text { shade-tolerant woodland species to } \\
\text { recover from grazing and trampling } \\
\text { D: Grazing exclusion leads to loss of } \\
\text { species of grassland habitats }\end{array}$ & $\begin{array}{l}\text { Caution with exclusion } \\
\text { (shifts in vegetation). The } \\
\text { development of founder } \\
\text { populations of non-native } \\
\text { species associated with } \\
\text { recovery from heavy } \\
\text { grazing disturbance, } \\
\text { should be the focus of } \\
\text { conservation action }\end{array}$ & $\begin{array}{l}\text { Lowland wet } \\
\text { oakwood } \\
\text { (UK) }\end{array}$ & $\begin{array}{l}\text { Cooper \& } \\
\text { McCann, } 2011\end{array}$ \\
\hline $\begin{array}{l}\text { B: Cattle greatly reduce the re- } \\
\text { generation of non-native black pine } \\
\text { D: Non-native black pines are } \\
\text { recruiting naturally where cattle } \\
\text { were excluded }\end{array}$ & $\begin{array}{l}\text { Cattle grazing is needed } \\
\text { to prevent black pine } \\
\text { recruitment }\end{array}$ & $\begin{array}{l}\text { Mixed beech- } \\
\text { oak-maple forest } \\
\text { with non-native } \\
\text { black pine } \\
\text { (France) }\end{array}$ & $\begin{array}{l}\text { Chauchard et al., } \\
2006\end{array}$ \\
\hline
\end{tabular}




\begin{tabular}{|c|c|c|c|}
\hline \multicolumn{4}{|c|}{ 4. Suggesting shift of management - acknowledging the potential of silvopastoral systems } \\
\hline $\begin{array}{l}\text { B: Shade, management of brush, } \\
\text { and savanna restoration } \\
\text { D: Damage of young trees, } \\
\text { seedlings }\end{array}$ & $\begin{array}{l}\text { Closed canopy, high } \\
\text { quality woods should not } \\
\text { be grazed and more } \\
\text { discussion and research is } \\
\text { needed on what types of } \\
\text { woodlands might be } \\
\text { suitable for silvopasture }\end{array}$ & $\begin{array}{l}\text { Broadleaf } \\
\text { (USA, Wisconsin) }\end{array}$ & $\begin{array}{l}\text { Mayerfeld et al., } \\
2016\end{array}$ \\
\hline $\begin{array}{l}\text { B: Important for the rural } \\
\text { community } \\
\text { D: Detrimental for timber } \\
\text { production }\end{array}$ & $\begin{array}{l}\text { The production of timber } \\
\text { and livestock is } \\
\text { incompatible. If the aim is } \\
\text { biodiversity conservation, } \\
\text { then wood pasture } \\
\text { management should be } \\
\text { considered }\end{array}$ & $\begin{array}{l}\text { Fagus sy/vatica } \\
\text { forest } \\
\text { (Iran, Azerbaijan) }\end{array}$ & $\begin{array}{l}\text { Noack et al., } \\
2010\end{array}$ \\
\hline
\end{tabular}

